UNITED STATES GEOLOGICAL SURVEY CHARLES D. WALCOTT, DIRECTOR

\title{
93 \\ GEOLOGIC ATLAS \\ OF THE \\ UNITED STATES
}

\section{ELKLAND-TIOGA FOLIO PENNSYLVANIA}
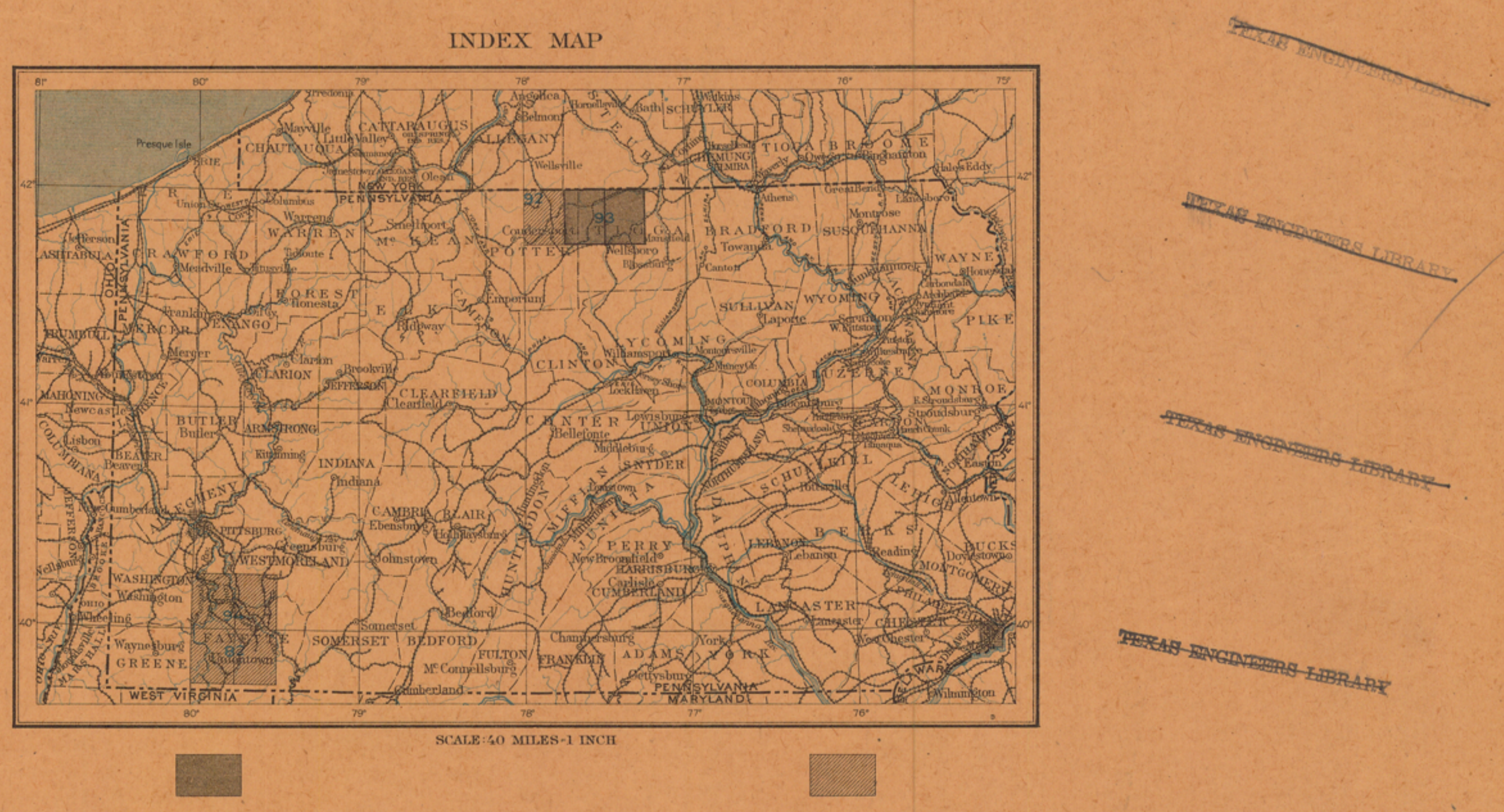

AREA OF THE ELKLAND-TIOGA FOLIO

CONTENTS

DESCRIPTIVE TEXT TOPOGRAPHIC MAPS AREAL GEOLOGY MAPS

ILLUSTRATION SHEET
AREA OF OTHER PUBLISHED FOLIOS

SURFICIAL GEOLOGY MAPS STRUCTURE SECTION SHEETS COLUMNAR SECTION SHEET

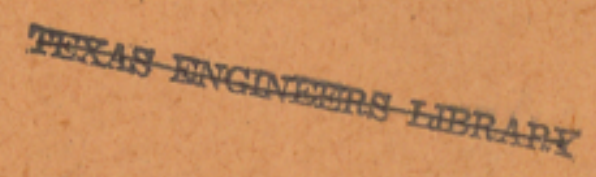

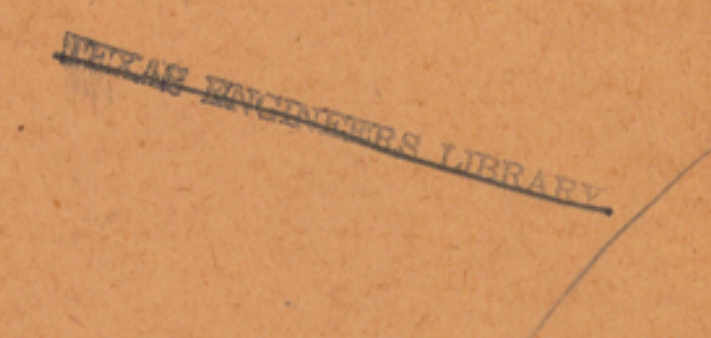

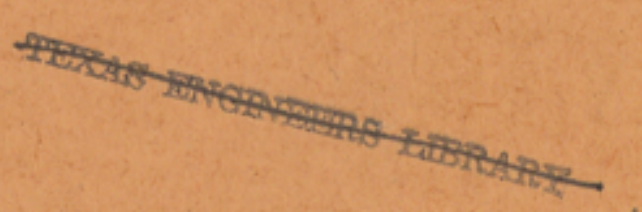


EXPLANATION.

tue Geological Survey is making a geologic map of the United States, which necessitates the preparation of a topographic base map. The atlas, the parts of which are called folios. Each folio consists of a topographic base map and with explanatory and deseriptive texts.

\section{THE TOPOGRAPHIC MAP}

The features represented on the topographic map are of three distinct kinds: (1) inequalities of surface, called relief, as plains, plateaus, valleys, hills, and mountains; (2) distribution of water, called drainage, as streams, lakes, and swamps;
(3) the works of man, called culture, as roads, (3) the works of man, called culture, as
railroads, boundaries, villages, and cities.

railroads, boundaries, villages, and cities.
Relief.-All elevations are measured from mean sea level. The heights of many points are aceurately determined, and those which are most
important are given on the map in figures. important are given on the map in figures.
It is desirable, however, to give the elevation of all parts of the area mapped, to delineate the horizontal outline, or contour, of all slopes, and to indicate their grade or degree of steepness. This is done by lines connecting points of equal elevation above mean sea level, the lines being drawn at regular vertical intervals. These lines are between each two contours is called the conto between each two contours is called the contour
interval. Contours and elevations are printed in brown.

The manner in which contours express eleva tion, form, and grade is shown in the
sketch and corresponding contour map
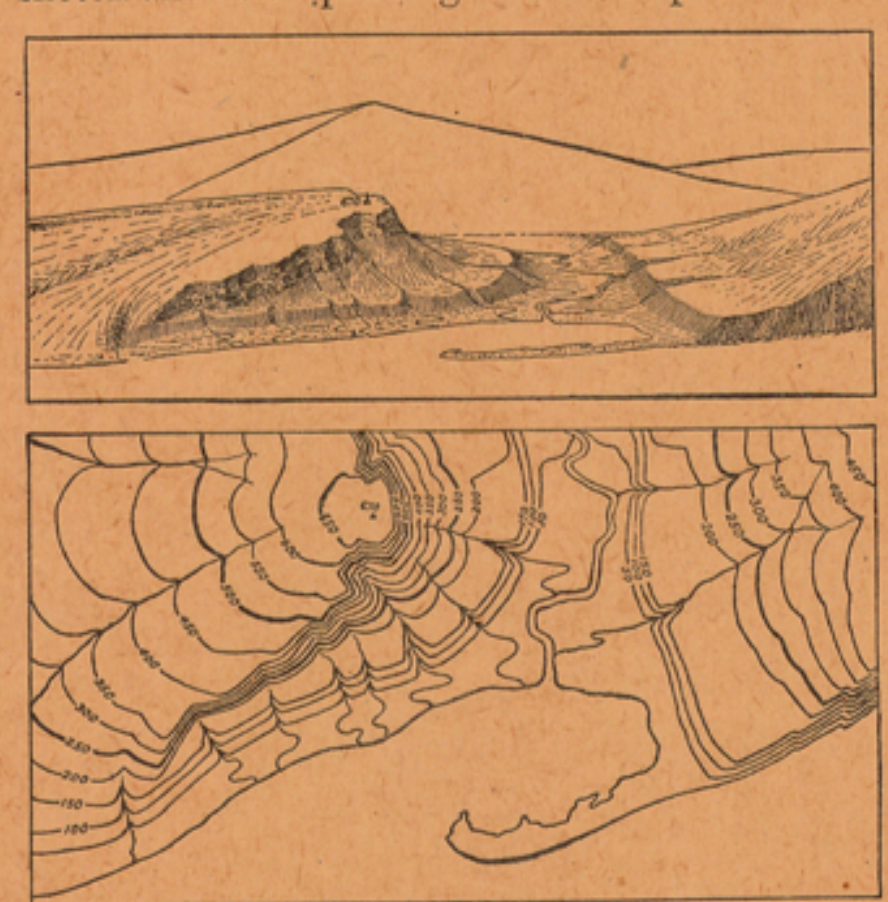

Fig. L-Ideal sketch and corresponding contour map.

The sketch represents a river valley between two hills. In the foreground is the sea, with a bay which is partly closed by a hooked sand bar. On
each side of the valley is a terrace. From the terrace on the right a hill rises gradually, while from that on the left the ground ascends steeply in a precipice. Contrasted with this precipice is
the gentle descent of the slope at the left. In the map each of these features is indicated, directly beneath its position in the sketch, by contours. The following explanation may make clearer the manner in whic

1. A contour indicates approximately a certain height above sea level. In this illustration the contour interval is 50 feet; therefore the con. tours are drawn at $50,100,150,200$ feet, and so on, all points of the surface 250 feet above sea ; and similarly with any other contour. In the space between any two contours are found all elevations
above the lower and below the higher contour. above the lower and below the higher contour.
Thus the contour at 150 feet falls just below the Thus the contour at 150 feet falls just below the
edge of the terrace, while that at 200 feet lies edge of the terrace, while that at 200 feet lies terrace are shown to be more than 150 but less than 200 feet above sea. The summit of the higher hill is stated to be 670 feet above sea; accordingly the contour at 650 feet surrounds it.
In this illustration nearly all the contours are In this illustration nearly all the contours are
numbered. Where this is not possible, certain numbered. Where this is not possible, certain and numbered; the heights of others may then be ascertained by counting up or down from numbered contour.
2. Contours define the forms of slopes. Since contours are continuous horizontal lines conform-
ing to the surface of the ground, they wind moothly about smooth surfaces, recede into all centrant angles of ravines, and project in passing
about prominences. The relations of contour curves and angles to forms of the landscape can be traced in the map and sketch.

3. Contours show the approximate grade of tours is the same, whether they lie along a clift or on a gentle slope; but to rise a given height on a gentle slope one must go farther than on a on a gentle slope one must go farther than on a
steep slope, and therefore contours are far apart on gentle slopes and near together on steep ones. For a flat or gently undulating country a smal
Fil contour interval is used, for a steep or mountain ous country a large interval is necessary. The Geological Survey is 5 feet. This is used for Geological Survey is 5 feet. This is used for
regions like the Mississippi delta and the Dismal wamp. In mapping great mountain masses, like hose in Colorado, the interval may be 250 feet For intermediate relief contour

o, 25, 50, and 100 feet are used.
Drainage-Water courses are indicated by blue Drainage.-Water courses are indicated by blue
ines. If the streams flow the year round the line is drawn unbroken, but if the channel is dry a part of the year the line is broken or dotted. Where a stream sinks and reappears at the surby a broken blue line. Lakes, marshes, and other bodies of water are also shown in blue, by appro priate conventional signs.

Culture.-The works of man, such as roads, ailroads, and towns, together with boundaries of townships, counties, and S

Scales. - The area of the United States (exclud. ing Alaska) is about 3,025,000 square miles. On map with the scale of 1 mile to the inch this would cover $3,025,000$ square inches, and to accommodate it the paper dimensions would need
to be about 240 by 180 feet. Each square mile of ground surface would be represented by a square inch of map surface, and one linear mile on the ground would be represented by a linear inch on the map. This relation between distance in nature and corresponding distance on the map is called the scale of the map. In this case it is "1 by a fraction, of which the numerator is a length on the map and the denominator the correspondThus, as there are 63,360 inches in a mile, the scale of " 1 mile to an inch" is expressed by Both of these methods are used on the maps of the Geological Survey.

Three scales are used on the atlas sheets of he Geological Survey; the smallest is $\frac{1}{150,000}$, the intermediate $\frac{1}{19.000,}$ and the largest $\frac{1}{6.500}$. These
correspond approximately to 4 miles, 2 miles, correspond approximately to 4 miles, 2 miles,
and 1 mile on the ground to an inch on the map. and 1 mile on the ground to an inch on the map.
On the scale $\frac{1}{c s, 500}$ a square inch of map surface represents and corresponds nearly to 1 square

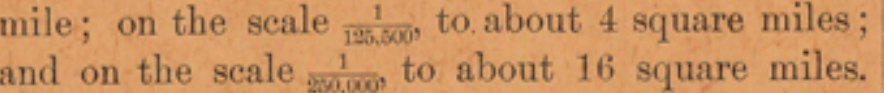
and on the scale $\frac{1}{\text { sow, wo }}$ to about 16 square miles.
At the bottom of each atlas sheet the scale is At the bottom of each atlas sheet the scale is
expressed in three different ways, one being a graduated line representing miles and parts of miles in English inches, another indicating distance in the met

Atlas sheets and quadrangles. - The map is eing published in atlas sheets of convenient size, which are boundea by parallels and meridians. The corresponding four-cornered portions of ter-
ritory are called quadrangles. Each sheet on ritory are called quadrangles.
the scale of $\frac{1}{250.000}$ entains one square degree, i. e., a degree of latitude by a degree of longitude; each sheet on the scale of $\frac{1}{120000}$ contains one-quarter of
a square degree; each sheet on a scale of a square degree; each sheet on a scale of
contains one-sixteenth of a square degree, The reas of the corresponding quadrangles are abont 4000,1000 , and 250 square miles, respectively. The atlas sheets, being only parts of one map of the United States, are laid out without regard to the boundary lines of the States, counties, or town-
ships. To each sheet, and to the quadrangle it hips. To each sheet, and to the quadrangle it The al represents, is given the name of some well-known of its minute particles or it may be accompanied town or natural feature within its limits, and at by a change in chemical and mineralogic composi-

the sides and corners of each sheet the n Uses of the topographic sheet. - Within the limits of scale the topographic sheet is an accurate and the landscape, map in hand, every characteristic feature of sufficient magnitude should be recog. bought or sold; save the engineer preliminary surveys in locating roads, railways, and irrigation ditches; provide educational material for schools and homes; and serve $n$
a map for local reference.

THE GEOLOGIC MAP

The maps representing areal geology show by colors and conventional signs, on the topographic base map, the distribution of rock formations on
the surface of the earth, and the structure-section map shows their underground relations, as far known and in such detail as the scale permit

$$
\text { KINDS OF ROCKS. }
$$

Rocks are of many kinds, The original crust rocks, and all other rocks have been derived from them in one way or another.

Atmospheric agencies gradually break up ignehave been formed on land surfaces since the earliest geologic time. Through the transporting ages and origins are carried to the sea, where, ages and origins are carried to the sea, where,
along with material derived from the land by the action of the waves on the coast, they form sedimentary rocks. These are usually hardened into conglomerate, sandstone, shale, and limestone,
but they may remain unconsolidated and still be called "rocks" by the geologist, though popularly own as gravel, sand, and clay.

From time to time in geologic history igneous
nd sedimentary rocks have been deeply buried, consolidated, and raised again above the surface of the water. In these processes, through the
gencies of pressure, movement, and chemical agencies of pressure, movement, and chemical ction, they are often greatly altered, and in this

Igneou they are called metamorphic rocks. Igneous rocks,- - These are rocks which have has been explained, sedimentary rocks were the igneous and sedimentary rocks of all ages molten material has from time to time been forced upward to or near the surface, and there consoli. dated. When the channels or vents into which
this molten material is forced do not reach the this molten material is forced do not reach the
surface, it may consolidate in cracks or fissures crossing the bedding planes, thus forming dikes or spread out between the strata in large bodies ross-cutting masses, called stocks. Such rocks are illed intrusive. Within their rock inclosures they cool slowly, and hence are generally of crys.
talline texture. When the channels reach the When the channels reach the
urface the lavas often flow out and build up volcanoes. These lavas cool rapidly in the air, acquiring a glassy or, more often, a partially crys.
talline condition. They are usually more or less porous. The igneous rocks thus formed upon the surface are called extrusive. Explosive action often accompanies volcanic eruptions, causing These materials when consolidated constitute reccias, agglomerates, and tuffs. The ash when rried into lakes or seas may become stratified,
to have the structure of sedimentary rocks.

The age of an igneous rock is often difficult or possible to determine. When it cuts across a edimentary rock it is younger than that rock, d when a sedimentary rock

Under the influence of dynamic and chemical Under the influence of dynamic and chemisal characteristic delineation of the relief, drainage,
and culture of the district represented. Viewing investor or owner who desires to ascertain the of rocks, forming superficial, or surficial, deposits d special forms. Much of this mixed material was
si. hanged by the development of planes of div sion, so that it splits in one direction more easily than in others. Thus a granite may pas
geiss, and from that into a micassehist. which have been deposited under water, whethe sea, lake, or stream. They form a very large wart of the dry land.

When the materials of which sedimentary rock re composed are carried as solid particles by deposit is called a mechanical sediment. These ay become hardened into conglomerate, sand tone, or shale. When the material is carried in solution by the water and is deposited withou the aid of life, it is called a chemical sediment;
if deposited with the aid of life, it is called an organic sediment. The more important rock formed from chemical and organic deposits are mestone, chert, gypsum, salt, iron ore, peat, ginite, and coal. Any one of the above sedi
nentary deposits may be separately formed, mentary deposits may be separately formed, o
the different materials may be intermingled i Sedimentary rocks are usually made up layers or beds which can be easily separated. These layers are called strata. Rocks dep
in successive layers are said to be stratified. The surface of the earth is not fixed, as it seems to be; it very slowly rises or sinks over wide xpanses, and as it rises or subsides the shore lines the ocean are changed: areas of deposition may land areas may sink below the water and become areas of deposition. If North America were flow over the Atlantic coast and the Mississippi ow over the Atlantic coast and the Mississipp Great Lakes; the Appalachian Mountains would Great Lakes; the Appalachian Mountains would
become an archipelago, and the ocean's shore wecome an archipelago, and the ocean's shor
would traverse Wisconsin, Iowa, and Kansas, and ould traverse Wisconsin, Iowa, and Kansus, and
extend thence to Texas. More extensive changes han this have repeatedly occurred in the past. The character of the original sediments may be changed by chemical and dynamic action so as to
produce metamorphic rocks. In the metamorproduce metamorphic rocks. In the metamot-
phism of a sedimentary rock, just as in the metsorphism of an igneous rock, the substances of which it is composed may enter into new com. binations, or new substances may be added. When these processes are complete the sedimenary rock becomes crystalline. Such changes their composition. A system of parallel division planes is often produced, which may cross the riginal beds or strata at any angle. Rocks Rocks of any period of the earth's history may be or less altered, but the younger formations have generally escaped marked metamor. hism, and the oldest sediments known, though cenerally the most altered, in some localities main essentially unchanged.

embrace the soils, clay inds, gravels, and bowlders that cover the surface, ration of the underlying rocks by atmospheric gencies or from glacial action. Surficial rocks hat are due to disintegration are produced chiefly by the action of air, water, frost, animals, and
lants. They consist mainly of the least soluble plants. They consist mainly of the least soluble parts of the rocks, which remain after the more oils are the most important. Residual accumu. lations are often washed or blown into valleys or ther depressions, where they lodge and form Surficial rocks that are due to glacial action are
Suss a formed of the products of disintegration, together with bowlders and fragments of rock rubbed from the surface and ground together. These are pread irregularly over the territory occupied y the ice, and form a mixture of clay, pebbles, nd bowlders which is known as till. It may in a sheet or be bunched into hills and ion. Further, the structure of the rock may be Sedimentary rocks.-These comprise all rocks many ways, producing a great variety of rocks. arble, and modify other rocks according oluble parts have been leached out, and hence
re known as residual products. Soils and sub. 


\section{DESCRIPTION OF THE ELKLAND AND TIOGA QUADRANGLES.}

General Geology by Myron L. Fuller. Pleistocene Geology by William C. Alden and Myron L. Fuller.

GENERAL RELATIONS.

Location and area. - The area mapped and described in this folio includes the Elkland and Tioga quadrangles, and is situated in northern Pennsylvania, immediately south of the norther boundary of the State and about midway between
its eastern and western limits. The Tioga quadits eastern and western limits. The Tioga quad-
rangle lies between longitude $77^{\circ}$ on the east and $77^{\circ} 15^{\prime}$ on the west, and the Elkland quadrangle between $77^{\circ} 15^{\prime}$ on the east and $77^{\circ} 30^{\prime}$ on the west.
Both lie between latitude $41^{\circ} 45^{\prime}$ on the south and $42^{\circ}$ on the north, and each includes one-sixteent of a square degree. The north-south length of each quadrangle is about 17.2 miles, the width about 13
miles, and the area 222.5 square miles, all of which lies within the limits of Tioga County. The Elkland quadrangle receives its name from the town of Elkland, in its northeastern part, on the Cowanfrom the town of Tioga, near its center.
for from the town of Tioga, near its center.
Relations to Appalachian province.-The Appalachian province, which extends from New York on the north to central Alabama on the south, and
from the Atlantic Coastal Plain on the east to the from the Atlantic Coastal Plain on the east to the
lowlands of the Mississippi Basin on the west, has been subdivided into three grand divisions. The eastern division is marked by the more or less
rounded, soil-covered ridges of igneous or altered sedimentary rocks which form the Appalachian Mountains proper; the central division by the long, straight or gently curved ridges, produced by the erosion of the strongly folded and faulted sediAppalachian Valley; and the western division by the deeply trenched plateau-like uplands, existing over the region of gently folded rocks to the north and northwest of the previous division, known as
the Allegheny Plateau. (See fig. 5, Illustration the Allegheny Plateau. (See fig. 5, Mlustration
sheet.) It is to this region of gentle folds and sheet.) It is to this region of gentle folds and
plateau-like topography that the Elkland and
Tioga quadrangles belong, the southwest corner of Tioga quadrangles belong, the southwest corner of
the former as measured across the strike of the the former as measured across the strike of the
folds to the south being about 40 miles from the Allegheny Front, which constitutes the wester margin of the Appalachian Valley.

TOPOGRAPHY Drainage. - The area included in the Elkland of a dissected plateau, or, in other words, a plateau
and Tioga and Tioga quadrangles, with the exception of a whil area in the southern quadrangle which drains southward into Pine Creek, and another small area in the extreme northeast corner of the Tioga quadrangle which drains northeastward into the Chemung River in New York, is drained by the Tioga River and its tributaries.

The Tioga River has its source in the mountainous belt crossing Tioga County in a southwesterly
direction from a point a little northeast of Bloss direction from a point a little northeast of Bloss-
burg to the southwest corner of the county. (See fig. 4, p. 8.) Near Blossburg, about 6 miles south of the limits of the quadrangles, the river turns to
the north, and flows, with a direction a little west the north, and flows, with a direction a little west
of north, across the Tioga quadrangle and into New of north, across the Tioga quadrangle and into New York State, finally joining the Chemung River back to the southeast, adding them to those waters North Branch of the Susquehanna in the northern part of Bradford County, Pennsylvania, whence Appalachian ridges and eventually empty into Chesapeake Bay.

The two main tributaries of the Tioga River in the region under consideration are the Cowanesque River and Crooked Creek. The former enters the
area in the northwestern portion of the Elkland area in the northwestern portion of the Elkland
quadrangle and flows in an easterly direction quadrangle and flows in an easterly direction
across the northern portions of the Elkland and Tioga quadrangles until it joins the Tioga River
near Lawrenceville. Crooked Creek rises in the near Lawrenceville. Crooked Creek rises in the the Elkland and Tioga quadrangles is that

and flows with a similar easterly course until it mpties into the Tioga River near Tioga.

Starting from Crooked Creek in the vicinity of Elkland quadrangle, and extending southwestward valley with a flat and marshy bottom lying only
a few feet higher than the streams at either end few feet higher than the streams at either end.
Waters entering the valley from the hills on either wide find their way out as sluggish, winding streams which empty in part into Crooked Creek on the
north and in part into Pine Creek on the south. The present streams are doing no work of erosion and have evidently played no part in the producvalley is clearly the result of the erosive action of a large and powerful stream; and a study of the occupied the valley until comparatively recent times, was a continuation of Pine Creek of Potter County. The diversion of the waters from the old channel into a new channel leading southward
from Ansonia to the West Branch of the Susquehanna at Jersey Shore took place partly through
henchia the ordinary processes of stream development and
partly through the agency of the ice sheet which covered the region in early Pleistocene times. The nature of the diversion will be considered
under the heading "Physiographic history," on pages 6 and 7 .

In general the Elkland and Tioga quadrangles are well drained with the exception of the flat the uplands, and marking, as will be seen later, the remnants of an old plateau, and of a few small by glacial drift. The obstructions of drainage due by glacial drift. The obstructions of drainage due
to drift barriers are usually of slight importance, hough in a few instances, as in the western porion of Chatham and the southern portion of
Farmington Township in the Elkland quadrangle, nd in the northeast portion of Charleston Township in the Tioga quadrangle, marshes from half
mile to nearly 2 miles in length occur. The only natural pond in the two quadrangles is a diminutive body, a few a
Farmington. Marsh.

Relief.-Briefly stated, the topography or relief which has been cut into by the streams until the
valley bottoms lie far below the general level of the uplands. The general level of the plateau is indicated by the mountainous belts of the area, the flat-topped crests of which are remnants of the old plateau surface.

Two of these belts occur within the area treated in this folio. The northernmost, the
Cowanesque mountain belt, enters the northern portion of the Elkland quadrangle near the village of the same name. Though much broken by the
Cowanesque River and its tributaries, it is repreCowanesque River and its tributaries, it is repre-
sented by prominent hills at numerous points on sented by prominent hills at numerous points on
each side of the valley. The second belt, which is limits of the Tioga quadrangle at a point a little north of the center. From here, under the name Elkland quadrangle a little south of Crooked Creek. Continuing under the name of Crooked Creek Mountain, it crosses the Elkland quadrangle, eventually leaving the western border at a point about 3 miles north of the southwest corner. From this point its name again changes, the western con-
tinuation being known as Pine Creek Mountain. The elevations of the crest lines of the mountain belts are very uniform, those of the much dissected Thove sea level, and those of the Crooked Creek-
Tioga belt from 2150 to a little over 2300 feet. Tioga belt from 2150 to a little over 2300 feet. Between the Cowanesque and the Crooked
Creek-Tioga mountain belt, and also to the south to Ansonia at the southern border, is a broad, open the more prominent of the two, enters the eastern $80^{\circ} \mathrm{W}$., across the quadrangle and enters the Cowanesque belt varying from 2000 to 2200 feet of the latter, are broad belt-like areas of rounded hills, the higher of which appear to rise to a some-
what general level of from 200 to 400 feet below the vel of the surface represented by the flat mounin crests. The slope of the surface of the suppoutheast. Its elevation, as recorded by the higher rests, appears to have been from 2000 to 2100 feet in the western portion of the Elkland quadrangle,
about 1900 feet in the vicinity of the boundary about 1900 feet in the vicinity of the boundary between the Elkland and Tioga areas, about 1850 in the southwestern portion of the Tioga quadrangle, and from 1600 to 1700 in the southeastern
portion. The difference of level between the upper and the lower plateau surface was due to the presence in the areas where the latter was develdetailed history of the production of the plateau urfaces, however, will be considered under the surfaces, however, will be considered under
heading "Physiographic history" (pp. 6-7). While the hardness of the rocks has been impor-
tant in determining the production of the broade tant in determining the production of the broader
topographic belts, the character of the streams has topographic belts, the character of the streams has
been the controlling factor in the production of the inor features. The large streams, and especially those which have been acting for long periods, have
eroded wider and flatter-bottomed valleys than the eroded wider and flatter-bottomed valleys than the
smaller and younger streams. Thus the smaller smaller and younger streams. Thus the smaller
streams, such as the minor tributaries of Tioga River, Crooked Creek, etc., flow in sharp $\mathbf{V}_{\text {-shaped }}$ alleys, while the rivers and larger creeks low wholly or partly in broad and relatively flatottomed valleys and are bordered by more or less valley bottoms is, however, due in part to fillings of glacial drift, upon which the present streams flow and upon the surface of which the flood plains
have been built. If this material should be removed, the wide rock bottoms of the valleys removed, the wide rock bottoms of the valleys
would probably show relatively narrow and sharput channels sunk to a depth of 50 feet or more below the general level of the old bottoms. The
erosion of these channels is supposed to have taken erosion of these channels is supposed to have taken
place at the beginning of the present geologic period (Pleistocene), and they are consequently
still well preserved. The tributaries of the larger treams, especially those of the Tioga River, show vidences of similar sharp cutting in relatively recent geologic times, but streams removed from Crooked Creek, show little evidence of tion.

This comparatively recent cutting has had an portant effect upon the topography in the region quadrangle. Nearly all the streams in this regio fow through sharp, gorge-like valleys and are requently bordered by perpendicular cliffs of considerable height. Elkhorn and Bear creeks in
Tioga Township show these cliffs to the best dvantage, but they are by no means uncommon in the other tributaries of the Tioga River north of the Tioga mountain belt. South of this belt
the erosion was much less pronounced, evidently he erosion was much less pronounced, evidently
indicating that the period of strong erosive action was too short to completely reduce the barrier presented by the hard sandstones of the mountain gion behind it from erosion.

By far the greater part of the valleys and chanls of the region have been produced by the action of streams which now occupy them. A prominent xception has already been noted in the case of the
wide valley between Middlebury Center and wide valley between Middlebury Center and
Ansonia. Other exceptions occur at the headwaters of Crooked Creek in Chatham Township and just south of Cobble Knoll in Charleston Township in the Elkland quadrangle, and at
several points in Charleston, Tioga, and Sullivan townships in the Tioga quadrangle. All of thes are due to the action of temporary streams during
the ice invasion, or to streams diverted from their the ice invasion, or to streams diverted from their down through its agency. These are known as ieology maps.

In general the glacial deposits have had relativel little influence upon the topography. Mino inequalities of the surface have been masked by a
smooth till coating, and in many cases the valleys smooth till coating, and in many cases the valleys
have been partially filled. The most marked deposits are the moraines, which, though of sligh elevation as compared with the rock hills, ar nevertheless, often 100 feet or more thick and are conspicuous by reason of their kettle-pitted surfaces. The irregular terraces and fans of glacial materials represented on the Surficial Geology graphic features.

DESCRIPTIVE GEOLOGY.

Formations represented.-The rocks exposed at the Elkland and Tioga quadrangle mey include not only thos rock, but also those loose, unconsolidated deposits silt, sand, gravel, glacial till, etc., which are likewise considered by geologists as rock, and which cur as fillings in the valleys, as ridges or patches loose material

The materials of the unconsolidated or surficial rocks are composed of fragments of varying size way or another from the consolidated rocks. The fragments range in size from the almost microscopic particles of the clays to large fragments and even bowlders. In the Elkland-Tioga area they have been derived almost wholly from the immediately underlying or from elosely adjacent rocks. A small percentage, however, came from greater distances; some even from sources as distant as
Canada. With the exception of a few recent stream deposits, practically all the materials comprising the surficial rocks have reached thei present position, either directly or indirectly, through the agency of an ice sheet similar to that now covering the surface of Greenland. This ice sheet started in the far North during the early part of the present geologic period and spread out over nearly the whole northeastern portion of North America, including the area now under discountry large quantities of the loose materials, and even portions of the rocks themselves, were taken up and transported greater or less distances. By the melting of the ice and by other causes this material was later set free and was deposited either in direct association with the ice or by the stream flowing away from its margin. These glacial deposits do not reach any considerable thickness The deposits laid down since the retreat of the ce are of even less geologic importance, being confined to thin coatings of silt forming the flood-plain surfaces along the larger streams, and a few fans and stream deposits of poorly assorted gravel. The materials of which the consolidated sedimentary rocks are composed were originally derived, in the form of gravel, sand, and mud, from an old waves, the resulting waste being carried to the margin of the seas then existing, and thence distributed by waves and currents as stratified or sedimentary beds. As time has elapsed, these beds mave been gradually consolidated by the chemical deposition of cementing materials about the grains of which the beds were composed.

In northern Pennsylvania and southern New York these sedimentary rocks reach a thickness of many thousand feet, and although only a small part of the whole can be seen at any point, or even in a single quadrangle, the deep cutting of the
streams, taken in connection with the moderate streams, taken in connection with the moderate
tilting of the beds, has been sufficient to expose in 
the area under discussion a thickness of about $3500 \mid$ the same thin and perfect lamination planes. feet of strata of Devonian and Carboniferous age. These exhibit many alternations of sandstone, shale, impure limestone, etc., but they may be grouped by their lithologic character in five formations, each marked by characteristic features. These lithologic divisions are, in ascending order, he Chemung, Cattaraugus, Oswayo, Mauch Chunk, and Pottsville formations. The first two are Devonian, the third is in part Devonian and in part Carboniferous, and the other two are Carbon-
iferous in age. Their general characters and relative iferous in age. Their general characters and relative thicknesses are shown on the Columnar Section
sheet at the end of the folio, and are described in detail in the following paragraphs.

DENONIAN FORMATIONS.

Chemung formation.- The name Chemung is here applied to a lithologic division which includes and thin limestones, having as its basal limit (not exposed in either of the quadrangles) the underlying bluish shales of the Portage formation, and as its upper limit the overlying red shales or the red or green sandstones of the Cattaraugus formafouna of the Chemung the typical marine excludes the overlying Cattarangus and lower Oswayo red and green shales and sandstones, which are characterized by a fresh- or brackishwater fauna, and which have sometimes been referred to the Chemung epoch.

The Chemung is the lowest of the formation encountered at the surface of the quadrangles, and is made up largely of a series of calcareous and soft shale and thin seams of impure limestone. soft shale and thin seams of impure limestone.
Gray, greenish-gray, and buff are ordinarily the Gray, greenish-gray, and buff are ordinarily the
predominant colors of both the sandstones and the shales. The calcareous sandstone is of the type which has come to be considered as especially characteristic of the Chemung, namely, a somewhat coarse, friable sandstone, crowded with open
cavities left by the solution of the fossil shells it riginally contained. It grades on the one hand into typical gray and somewhat flaggy sandstone and on the other into more or less impure limesurface the sandstones sometimes appear to be the predominant rock, but this is probably due in great part to the fact that they are more resistant to disintegration than the soft and finely laminated shales which the deep well records and the longer stream sections show to constitute the larger portion of the formation.

The limestones are commonly of a dark bluishgray, sometimes almost black, argillaceous type whole of the mass sometimes being made up of whole of the mass sometimes being made up of
fragments of shells. The limestones are, in general, most abundant in the upper portion of the formation, the thickest beds apparently occurring in the upper 100 or 200 feet.

The shales are predominantly of an olive color, though gray and green beds are by no means
uncommon. A single bed of bright-red shale, less uncommon. A single bed of bright-red shale, less than 2 feet in thickness, was noted, near the crest
of the anticline in the southern portion of the Tioga quadrangle, in a position probably 300 fe or more below the top of the Chemung. This, with the thin lenses of iron ore occurring at reddish-brown shales and sandstones occurring somewhat lower horizons and exposed in the section along the Erie Railroad north of Tioga station, are probably the only representatives in the area of the lower red series (Oneonta formaFranklindale, and other localities in the western half of Bradford County, a few miles southeast of the Tioga quadrangle.

The sandstones of the Chemung are extremely variable in color and texture, but the gray and buff types predominate throughout the larger part $\begin{array}{ll}\text { of the formation. The beds are rarely massive, } & \text { the latter measurement being at the old mine on } \\ \text { but are generally marked by bedding planes which } & \text { the hill about } 1 \frac{1}{2} \text { miles southwest of Mansfield. }\end{array}$ subdivide the rock into thin and rather irregular East of the river the ore, which is possibly at a layers. In the upper part of the formation, at an slightly lower horizon, is much darker, more interval of from 60 to 100 feet below the red beds massive, and far less fossiliferous than the ore west
which rest upon it, there is, in the southern half
of the river. Another bed of similar character is which rest upon it, there is, in the southern half
of the Tioga area, a prominent bed of green cross-
said to overlie the bed just described at an interval of of the Tioga area, a prominent bed of green cross-
bedded sandstone of the Cattaraugus type, having 50 feet at one point, but it is probably a local lens. which are several feet in diameter. (See fig. Illustration sheet.) The concretions are composed bands. They , frequently in perfect concentric of the other distinctive beds, appear to be most abundant near the top of the formation. Ripple stones, and an imperfect cross bedding characterizes many of the more sandy beds.

In a few localities in the Tioga quadrangle thin been noted. These are generally composed almost localities are somewhat stained by iron oxide. The conglomeratic layers appear to be most abunlant near the upper limits of the Chemung, though few pebbly layers and at least one strong bed of
conglomerate occurs well down in the formation. Among the localities at which conglomerates have been noted are the hill west of Mansfield, over
which runs the road leading south from Mann Creek, the hill immediately north of Mansfield and next to the river, the slopes just north of the road at the east edge of the Tioga quadrangle a mile of the valley leading eastward from the south side 2 miles north of the same point. The bed at the last locality seems to be several feet in thickness to 3 or 4 feet in diameter, which now cover the atic character and becomes a gravish sandstone
and which on exposure bleaches almost white.

Of the different beds of the Chemung the iron ores are the most distinctive in character. They occur mainly along the anticline in the southern outcrop has been noted on the south side of the anticline north of Crooked Creek. The beds are very thin, varying from a few inches to 3 feet in of the formation, and the second appears to be 300 The apro blow the first. bed. It has been opened up at several points and appears to be fairly persistent along the northern
flank of the anticline, but it has not been definitely flank of the anticline, but it has not been definitely
recognized on the south flank. In general it is rather bright-red granular hematite, the lower portion of which is usually impure and filled with
ossils. Its thickness varies from $1 \frac{1}{2}$ to 3 feet. It lies in close proximity to the lowest of the red
beds of the Chemung-Cattaraugus transition, occurring a few feet below the red beds on the west side of the Tioga River and a

The lower ore horizon is probably represented by a number of thin beds occurring in nearly the
same geologic position but possibly overlapping in places. The locations of the various mines, prospects, and outcrops are shown on the geologic map. Tiver the ore is uniformly a thly fossiliferous red oolitic hematite and varies
With the exception of the upper 100 or 200 feet, | it at the middle of its western boundary. It is which sometimes shows evidences of the approach- narrowest where it leaves the quadrangle, having ing change to Cattaraugus conditions, the general at that point a width varying from $2 \frac{1}{2}$ miles on character of the Chemung sediments appears to be the uplands to about 7 miles measured between it fairly uniform throughout. Beds of sufficiently extreme limits in the valleys. At the boundary distinct lithologic character to admit of tracing if between the quadrangles its width is from 8 to 9
they were continuous over any considerable area, miles. East of this point the Cattaraugus rock they were continuous over any considerable area, miles. Last of this point the Cattaraugs rock such as the iron ores and the more distinctive of
the limestones, sandstones, and conglomerates, are in Pennsylvania or in New York.

known, but no beds which could be recognized
The second belt enters the Tioga quadrangle known, but no beds which could be recognized
with certainty at widely separated points have been little northeast of Mansfield, passes southwestward with certainty at widely separated points have been
seen. The absence of traceable beds has added
to Canoe Camp, then westward and southwestward seen. The absence of traceable beds has added
greatly to the difficulty of working out the geologic structure of the region.

The general character of the Chemung forma tion, and the rapid alternations of sandstones and shales, are well brought out in the following section measured by Dr. E. M. Kindle along the railroad northward from Tioga station on the Erie conglomerate lenses, of limited distribution, have horizons. The upper horizon lies close to the top

single bed, usually known as the Mansfield ore below the top of the formation:

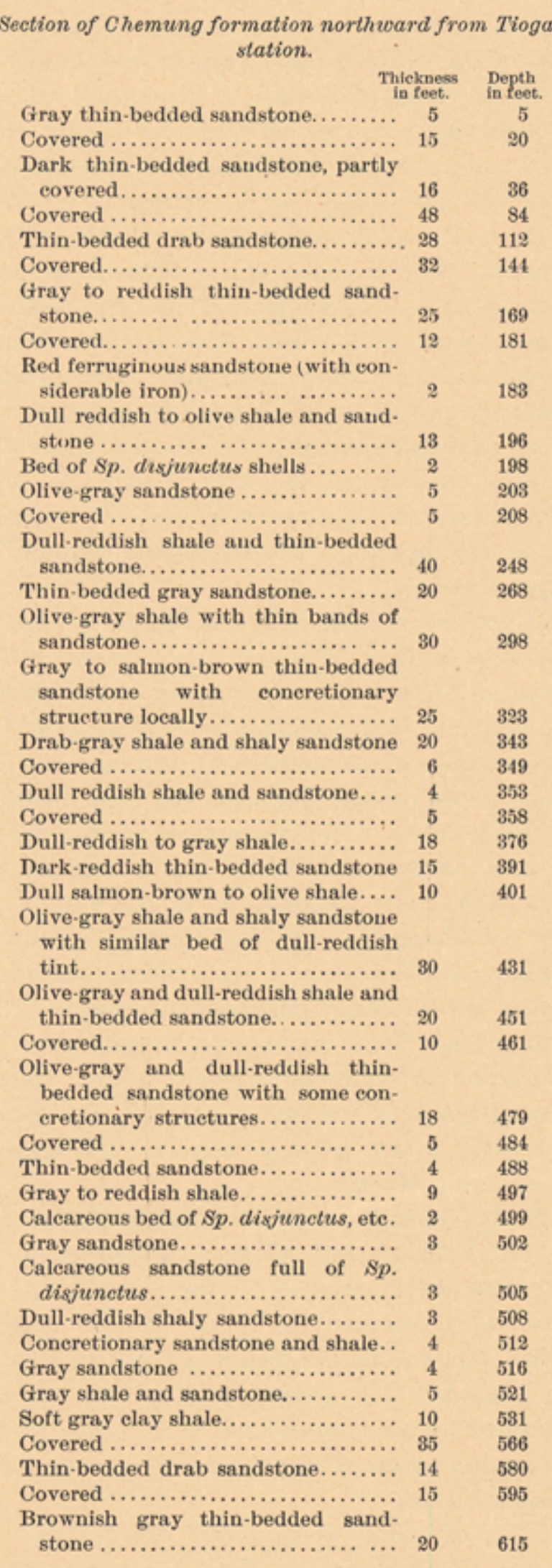

The upper limit of the Chemung formation is il defined, as the change from the Chemung to the Cattaraugus conditions is not abrupt. Beds of beds partaking more and more of the nature of the verlying Cattaraugus formation. Even after the appearance of beds of red shale or sandstone, same fossils as the Chemung occur at intervals through a range of from 50 to 200 feet or more. In mapping, however, it has been necessary to
select some horizon as marking the upper limit of select some horizon as marking the upper limit of
the typical Chemung, and that of the bottom of the lowest red bed has been chosen. Between this horizon and that of the lowest of the heavy red underlying and the overlying formations and are
und nderlying and the overlying formations
regarded and mapped as transitional beds.

The distribution of the Chemung sedim

own by the geologic maps, and little needs to be said beyond the fact that they are brought to the surface by two well-marked anticlinal folds. The
first of these enters the Tioga quadrangle from the northeast near its northeast corner and crosses it
with a trend a little south of west. It enters the with a trend a little south of west. It enters the
Elkland quadrangle in its northern half and leaves through East Charleston and Charleston, and across the southeast corner of the Elkland quadrangle. Its greatest width in the area is along the Tioga River, where it is exposed within the quadrangle for a distance of 7 miles. Its full width along the river, however, is probably 9 miles o more. It is relatively narrew on the uplands on each side of the Tioga River,
from a little over 2 to 5 miles.

In both belts the greatest thickness exposed is along the Tioga River. In the northern belt it is are brought to the surface, while in the souther belt about 800 feet of the beds are exposed.

DEVONO-CARBONIFEROUS FORMATIONS.

Commencing with the beds of red shale which have been taken as marking the beginning of the formation succeeding the Chemung, and continuing upward to the Mauch Chunk formation, there is in the Elkland-Tioga region a great sequence of reridy alternating shales and sandstones which geological survey as the Catskill and Pocono forgeological survey as the Catskill and Pocono for-
mations. At their base they grade into the rocks of the Chemung formation, at a horizon some distance below that which marks the top of the same formation farther west, while at their top they are overlain by either the Mauch Chunk shales of the upper portion of the Mississippian or by the Sharon conglomerate of the lower part of the Pennsylvanian series of the Carboniferous. Notwithstanding this considerable difference in age between the lower and the upper portions of the ogic characteristics has been discovered, and the beds have, therefore, been referred to a transitional group known as the Catskill-Pocono.

Bright-red shales predominate in the lower porupper portion, but the two are not separated by any sharp break. The differences are so marked, however, that, notwithstanding the gradual transition, the series has been separated into two formains. The terms "Catskill" and "Pocono" as used in their typical localities are based on distinctions which do not hold in the region under pplied The nas applied. The names here adopted are Cattaraugu greenish-gray sandstone division. The Cattaraugu ed from Cattaraugus County, Y., and the Oswayo formation from Oswayo Creek, which empties into the Allegheny River the southeast corner of Cattaraugus County. the vicinity of Oswayo Creek and elsewhere in the outheastern portion of that county. is also marked by a general change from an abundant marine fauna, consisting mainly of brachiopods, to a much less abundant fauna, mainly of fresh and brackish water, and consisting largely of fish mains, ferns, etc. Occasional layers of the foration, however; carry a few salt-water lamelli-

The upper limit of the formation is placed at the op of the uppermost of the prominent and pertistent red beds. The actual point at which this
ransition occurs is variable and does not admit of direct tracing. In general, however, it may be aid that all the larger and more important red beds occur within a vertical range of 500 feet above the base of the first prominent red bed, while above this interval only occasional thin beds of relatively
restricted area are found. On the map the top of probable that about 2000 feet of Chemung beds tion and green or greenish-gray sandstones in the and Oswayo, the former embracing the lower or red-shale division and the latter the upper or

Cattaraugus formation - The Cattaraugus formaiderable red bed above the Chemung. The point 
the formation is drawn arbitrarily at the top of interval of 500 feet.

The rocks of the Cattaraugus formation consist of a practically unfossiliferous succession of red shale and red and brown sandstone interspersed at
intervals with gray and greenish shales and sandintervals with gray and greenish shales and sand-
stones. If the formation is made to include the interval from the lowest to the highest of the per-
sistent red beds, it is probable that the actual sistent red beds, it is probable that the actual
thickness of the red material will not exceed onethickness of the red material will not exceed one-
half of the whole thickness, the remainder being taken up by the green and gray shales and sandstones. The red beds, nevertheless, are the most tion.

Of the gray and green shales and sandstones, the green sandstone is the most conspicuous. This is largely because of its hard and siliceous composition, which causes it to resist erosion and stand out more conspicuously than the softer portions of greenish color on the exposed surface. It greenish color on the exposed surface. It both the sloping and the horizontal layers being unusually thin and perfect. Of the gray and green shales, the former predominate and form an important part of the formation. Some of the
lighter beds carry ferns and other plant remains lighter beds carry ferns and other plant remains.
Both shales and sandstones frequently exhibit Both shales and sandstones frequen
ripple marks and other shore features.

ripple marks and other shore features.

especially the relation the Cattaraugus formation, or greenish-gray materials, etc., is well shown in the section at Seely Creek, a small tributary entering Lambs Creek from the north about a mile above its mouth, in the northern part of Richmond Township, in the Tioga quadrangle.

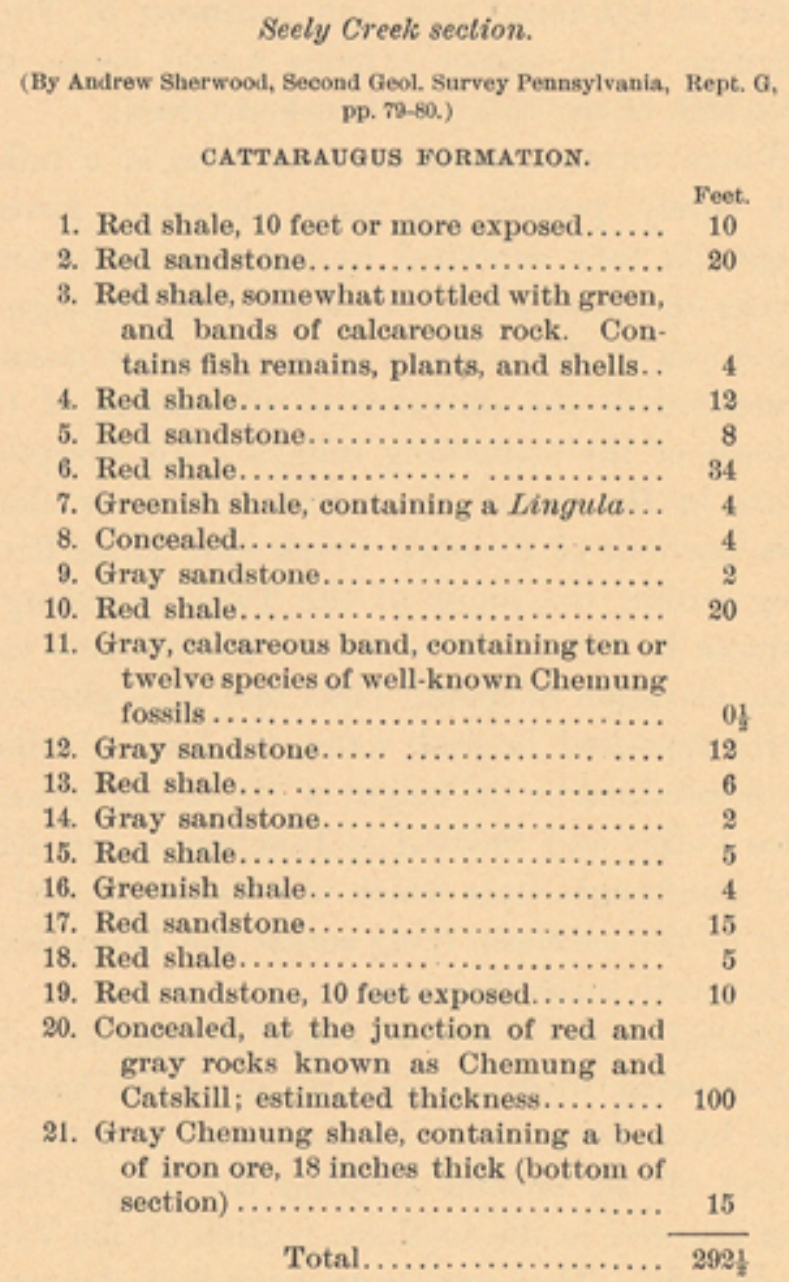

The red shales of the Cattaraugus formation come in with the greatest suddenness and in strongest development in the southeastern portion of the area. Here single beds of red materials, consisting of alternating shales and sandstones, up
to 100 feet or more in thickness, have been noted. to 100 feet or more in thickness, have been noted.
To the west and northwest, however, the red beds are much thinner and are separated by more pronounced beds of other material.

The rocks of the Cattaraugus formation are most widely distributed in the northern half of the Elkland quadrangle, where they occupy the central portion of the syncline along the Cowanesque River. The next definite belt is along the south flank of the broad anticline covering the northern portions of both quadrangles. Starting about $1 \frac{1}{2}$ miles southeast of Jackson Summit, at the eastern edge of the Tioga quadrangle, the belt extends with a trend a few degrees south of west across both quadrangles, crossing the Tioga River a little above Tioga, passing through Hammond, Keeneyville, etc., and finally leaving the Elkland quadrangle near Azelta. On the south side of the
Tioga-Crooked Creek mountain belt the CattarauTioga-Crooked Creek mountain belt the Cattarau-
gus rocks extend in a belt nearly parallel with the iver and Stephenhouse Run in the Tioga quadpreceding, starting near Mill Creek at the eastern rangle. Beyond a slight show of red soil 80 feet edge of the Tioga quadrangle and passing a little below the Sharon conglomerate at the head of Elkland and Tioga. rooked creeks and their tributaries. The southern elt connects with the preceding through the valley Hills Creek, Tioga River, and Mill Creek, in the Tioga quadrangle. Slight thicknesses of Cattaraunticline in the higher of the hills along the

Oswayo formation. - The Oswayo formation includes the thick series of green and gray sandenses of red shales lying above the uppermos of the stronger red beds and below the Mauch

The green or greenish-gray sandstones predomique, and because of their siliceous character freas distinct shelves and tables. On the exposed urface the sandstones are generally of a dishey are of a dirty-buff or brown color, distinctly rgillaceous, and frequently specked with limonitic pots, probably due to the decomposition of minute crystals of pyrite. On continued exposure to the
weather the sandstones seem to lose their greenish inge and become light gray, presumably because of the washing away of the finer products of disintegration and decay, leaving only the insoluble quartz to show upon the surface. Like those of are almost invariably cross bedded, and are characterized by minute mica plates along the laminaion planes. In fact, the greenish sandstones of the two formations are so similar that it is impo sible to distinguish them by lithologic character
Ripple marks and other shore features are not nncommon. and green shales as far up as the Sharon conglomerate. On the map, however, the boundary of the
Oswayo formation is placed just below the point at Oswayo formation is placed just below the p
which decidedly red beds begin to reappear. The rocks of the Oswayo formation are limi to the uplands along the Tioga-Crooked Creek mountain belt and to a few of the higher points of western portion of the Elkland quadrangle. CARBONIFEROUS FORMATIONS.

Mauch Chunk formation.-On the hills on both sides of the headwaters of Painter Run, near the eastern limits of the Tioga quadrangle, and directly red and green shales and sandstones, including a red and green shales and sandstones, including a
bed of iron ore and at least one of fire clay. Although no fossils have been found in these beds, their strong physical resemblance to the Mauch Chunk and their occurrence in the proper position
point strongly to the probability that they belong point strongly to the probability that they belong
to this formation, and they have been so mapped. The thickness as measured from the lowest recog-
nized red bed overlying the Oswayo appears to be little over 100 feet.

The following section, which was determined by surface indications and one or two pits, shows something of the character of the upper portion of the
formation. It starts at the top of the hill east of Painter Run, the upper bed being a few feet belo the horizon of the Sharon conglomerate.

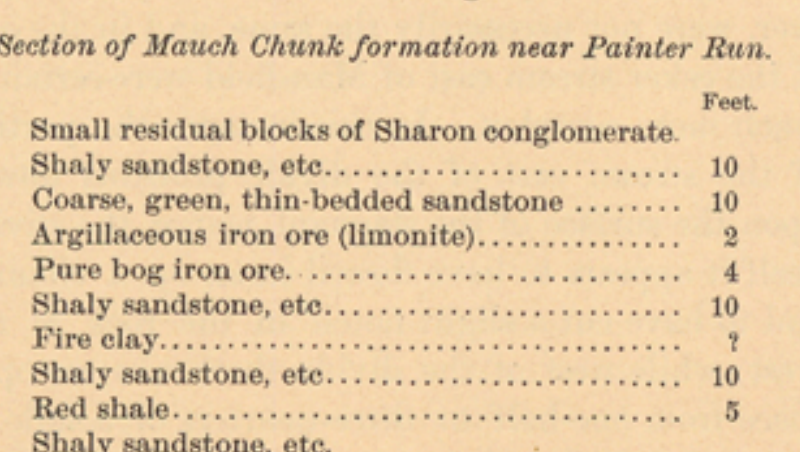

Red and green shale beds of the Mauch Chunk redion have been recognized in the crest west of of Charleston Township. In the Elkland quadsouthern edge of the Tioga quadrangle. from 1100 feet.

The upper portion of the Oswayo formation grades insensibly into the Mauch Chunk where the latter is present, sandstones of the Oswayo
type continuing to appear interbedded with red as pointing to the presence of Mauch Chunk beds| Of the till deposits two types, the morainal and Elkland quadrangle. As there the till sheet or ground moraine, have been recogstrong probability of an unconformity at the base nized in this area, while the stratified drift includes
the Sharon conglomerate which may cut out the a part of the morainal deposits, esker and kame Tauch Chunk at times, the latter fort out the been mapped only where its presence is well Pots

Pottsville formation.-The Pottsville is the uppermost of the formations exposed in the Elkland and Tioga quadrangles. In this region it may be sisting of a well-defined conglomerate fromer con- 60 to 100 feet thick, known as the Sharon conglomerate, and the upper consisting of sandstones and shales plant remains, found by Mr. David White in eighboring locality, as Pottsville in age.

The Sharon conglomerate is composed almost entirely of quartz and is frequently a coarse sand-
stone rather than a conglomerate. The pure white stone rather than a conglomerate. The pure white
color of the grains and pebbles of quartz gives the rock a bright, almost white appearance, quite different from that of other rocks with which it is
associated. Though sometimes thin bedded, it is commonly massive in character, and gives rise to somewhat conspicuous cliff-like outcrops. This
cliff-forming character, however, is not nearly so cliff-forming character, however, is not nearly so
prominent in the Elkland and Tioga quadrangle as at many other points in the State, and is apparently confined to certain of the more massive layers, horizons not necessarily occu

The bed of conglomerate, though extremely resistant to the action of weathering and erosion, is
much broken in places. This is probably due in large measure to the weathering out and removal of the softer and more easily eroded beds underlying the conglomerate, which is thus left unsupported. Large bowlders are frequently broken of and slide downward, burying the slopes with cumulations of débris.

The conglomerate caps several of the crests of southern portion of the Elkland quadrangle, but to the east does not occur until the crest west of
the headwaters of Painter Run, near the eastern the headwaters of Painter Run, near the eastern
edge of the Tioga quadrangle, is reached. East of the run the conglomerate has disappeared as a bed, but is still represented by bowlders scattered over the top of
its sides.

The upper sandy division of the Pottsville is represented in the area by a few feet of sandstone
and shale occurring just west of the head of Big Asaph Run, at the extreme western edge of the Elkland quadrangle.

\section{PLEISTOCENE DEPOSITS.}

The deposits of the Pleistocene period in the

(1) those which were laid down either directly or indirectly through the agency of the great ice sheet which covered the region in the earlier portion of
the period, and (2) those which have been deposited through the agency of ordinary stream or other water action since the final disappearance of the ice
sheet. The former are known as glacial deposits sheet. The former are known as glacial depo
and the latter as post-glacial or recent deposits.

\section{The glacial deposits consist of}

were picked up by or dragged along in the bottom of the ice sheet as it moved southwestward across the region, or were transported by its associated
streams. The material has all been moved from its original location and is known by the name of drift. This drift was deposited directly by the ice, being either set free by the melting of the
portion into which it had been frozen, or simply portion into which it had been frozen, or simply between the drift in the bottom of the moving ice and the overridden surface became so great as to by either of these methods usually consists of a by either of these methods usually consists of a
heterogeneous mixture, including all grades of heterogeneous mixture, including all grades of
material from clay to large bowlders, and is known as $t i l l$. Drift which is not deposited directly from he ice, but which has been taken up, transported, d finally deposited in a more or less distinctly types, depending upon minor features of origin. deposits, morainal and frontal terraces, and the Ider clays, sands, and gravels of the valley fillings. Till sheet or ground moraine.-By far the most abundant of the deposits laid down by the direct ation of the ice are those which belong to the class of till known as ground moraine, and which were deposited beneath the ice sheet, as we have seen, by the melting of the basal débris-laden layer or of friction.

The till thus deposited consists of a matrix of fine material, derived partly from the old soil and partly from the grinding and pulverizing of the rock fragments, in which are embedded angular and slightly worn fragments of rock varying from
mere chips or pebbles to bowlders several feet in liameter. In places this fine material is more or
ding less clayey, but since it is very largely derived from the underlying rocks, that of the Elkland and Tioga region is generally rather sandy. Not infrequently there occur rock fragments which show smoothing, polishing, and striations like those
which have been noted on certain exposed rock which have been noted on certain exposed rock
surfaces and which have resulted from the grinding ction of the rock material carried or dragged along at the bottom of the ice sheet. Such erosion phenomena are characteristic of glaciation as disOne of the striking features of the till of
Ong rea, however, is the small amount of wear to been subjected. The till is full of fragments of ock as fresh and angular as if but recently broken. Almost everywhere in the cultivated portions of the area one sees piles and fence walls of flat fragnents of rock, of which only a small number give vidence of having been ground beneath the ice of the glacier. This angularity is undoubtedly very most of the rock of this region, in consequence of
which the bowlders, instead of becoming smooth nd striated, as would a limestone of ordinary are frequently broken to pieces. Certain layers of the Chemung and Portage formations are of an impure type of limestone which gives somewhat
hicker bowlders, sometimes found beautifully polished and striated.

Sections permitting accurate measurements of the thickness of the drift are infrequent, and because of their slight depth are of little value except as indicating the minimum amounts of filling at local points. The frequent outcroppings of the underying rock strata, however, indicate that the average depth must be very moderate. This is par-
ticularly true in the mountain belts, where rock ledges are often exposed. In other parts of the rea the lack of these jutting ledges, together with he beautifully rounded contours typical of a welllaciated region, give the impression that the drift nantle is of considerable thickness; yet even here road cuttings only a few feet in depth are likely to expose the soft shaly beds of the Chemung formation, showing that in reality the forms of the hills are due rather to erosion
drift upon their surfaces.

While it is often impossible to determine with any accuracy the thickness of the till at a given point, there are three distinct belts within the limits of each of which the thickness does not vary greatly from a certain average depth. The outhern belt includes the region south of the rooked Creek-Tioga mountain belt. In this region the till sheet is relatively thin, rock freuently showing through, and the soil over a large art of the area is essentially sedentary in character. The thickness of the till would perhaps average acing the Tioga River, however, especially on the west side, there are in places very thick accumulains of till, some of which show a considerable ercentage of foreign material.

The second or middle belt includes the area of the Crooked Creek-Tioga mountain belt. The tops of the mountains are destitute of glacial deposits, with the exception of a few transported pebbles and bowlders and occasionally a very thin
coating of till. The valleys, however, were in which the greater part of the stony material has argely due to the brittle, thin-bedded character of bedding and texture, split up into thin plates which 
many cases deeply filled by drift deposits, which / ice from the region, and are therefore described as $\mid 130$ feet in the deposits east of Phillips, and probave subsequently suffered deep cutting and erosion. remainder of the Elkland-Tioga area, the till is remainder of the Elkland-Tioga area, the till is
much thicker than in either of the other two belts. Exposures of thick till are numerous and the surExposures of thick till are numerous and the sur-
face almost everywhere shows by its topography face almost everywhere shows by its topography
that the till is relatively thick. Rock outcrops that the till is relatively thick. Rock outcrops except in ravines are rare. As in the southern belt, the hillsides facing the rivers are often deeply banked with till, which possibly in places along the Cowanesque River reaches a thickness of 100 feet or more. The thickness on the general will probably average rather over 10 feet. against the sides, but it also occurs as fillings of considerable depth in nearly all the valleys. In all but the broader of these the till constituent of the drift predominates, though important amounts of stratified drift deposited by waters derived from of stratified drift deposited by waters derived from
the melting ice sheet and concentrated in the valleys the melting icesheet
are usually present.

Where considerable deposits of drift occur in the valleys, especially in the deeper-cut valleys of the mountain belts, the slopes do not extend regularly from top to bottom, but part way up the declivities become less steep, forming somewhat indefinite sloping shelves, above which the slopes again rise steeply. The shelves probably represent in many instances the original levels of the drift fillings, into which the sharp, steep-sided channels of the lower portions of the valleys have been subsequently cut. In other cases the shelves may have resulted from irregularities of deposition. The sharp V-shaped valleys are especially characteristic

taries of Pine and Marsh creoks.

In the lower parts of some of the other valleys, such as those of Troups and Jemason creeks in the Elkland quadrangle, the filling is so disposed as to give broad valley bottoms sloping gently to the streams. Both these creeks have been crowded close against the sides of their valleys, and have here cut their channels in drift and rock.

The amount of valley filling is not readily estimated. The streams frequently cut into or expose the underlying rock beds, but this usually
occurs where the creek is crowded against one side of the valley. The sinking of water wells, however, shows that at many points the drift is 30,50 , or even 75 feet deep in the middle of the valleys. but consists in part of stratified drift, which in till, may even form a considerable portion of the deposit. A feature which attracts the attention of anyone studying the drift of this area is the great preponderance of local material. Only a few scattering derance of local material. Only a few scattering
fragments have been derived from rocks other than those of the quadrangles or of contiguous regions. Some, however, have been derived from regions as
remote as the Adirondacks or Canada. These remote as the Adirondacks or Canada. These
occur distributed throughout both quadrangles, occur distributed throughout both quadrangles,
but are most abundant in the east, though even here only a few scattering fragments can usually be found at a single exposure. To one
familiar with the glacial deposits of the Mississippi Valley this extremely local character of the rock fragments is a striking feature. In certain parts region as much as 10 to 20 per cent of the stony body of the drift was derived from the crystalline rocks of Canada, while sometimes as much as 95 per cent of the surface bowlders came from beyond per cent of the sureat Lakes.
the Gre

Retreatal moraines,-Besides the ground-moraine or till sheet which accumulated beneath the ice in
ond the manner already explained, there is another class of drift deposited in direct connection with the ice,
which, though perhaps of no more importance, is often more conspicuous. This is the class of
deposits known as moraines, the materials of which deposits known as moraines, the materials of which
have accumulated along the margin of the ice sheet have accumulated along the margin of the ice sheet at various periods of its history. The deposits occur as irregular patches which often form more
or less well-developed belts. The materials consist of both unassorted drift or till and assorted or stratified drift, the former having been set free at the margin of the glacier by melting of the ice, and
the latter having been deposited by streams and rivulets issuing from the margin. In the Elkland and Tioga quadrangles the morainal deposits were laid down during temporary halts or slight read- than in the majority of the morainal deposits of vances which interrupted the general retreat of the the area. The thickness is known to be as great as

ably reaches similar depths southeast of Elkland,

The morainal deposits are most extensively the Tioga and Cowanesque rivers. In places they robably reach a thickness of 100 or even 200 feet They are generally marked by prominent knolls
and hummocks and by irregular or bowl-like nd hummocks and by irregular or bowl-like ed drift are well represented, not only in the noraines as a group but in the individual deposits. For this reason it has not been possible to separate the till from the stratified moraines. It may be
said, however, that the stratified material predomites in the majority of the morainal deposits along The Tioga River.

The oldest of the morainal deposits in the Elkand and Tioga quadrangles are those which occur nd northeast they become progressively younger and younger until the limits of the area are reached. In their broader relations the deposits appear fall into a number of groups, two

The first or oldest group, so far as its deposit re concerned, is the least important, and is limited
a fair-sized area along Elk Run and a few other mall patches in the southeastern portion of the Tioga quadrangle. These deposits probably m
relatively short halts in the glacial retreat.

The second group begins at the junction of Mill The Tioga important break to the mouth of Painter Run. From this point to the junction of Lambs Creek and the Tioga River there are thick drift deposits, which do not, however, possess a distinct morainal which do not, however, possess a distinct morainal
topography. Farther west the deposits again take a typical morainic character and continue with few interruptions as a well-defined belt to the
dge of the quadrangle, in the northern portion of Charleston Township. The morainal deposits north Wellsboro probably mark a continuation of the same group. To this belt, which constitutes
the best defined series of morainal deposits in the gion, the name Mill Creek moraine is here applied. The moraine is parallel with the south edge of he Tioga mountain belt, a position which appears
o have resulted from the influence of the highlands upon the position of the ice margin. Its deposits other similar deposits in the area, and have had more important influence on the drainage, several of the streams having been forced to seek new and The

The third and youngest group of morainal orth of the Mill Creek moraine. Their deposition began with the first retreat of the ice from its
position along this moraine; hence the earlier hem are continuous or at least intimately associated with its deposits, especially along Mill Creek and Tioga River. Included in the third group are two rather definite though interrupted bands of River north of Tioga and the other along the
Ring Cowanesque River and its tributaries to the western limits of the quadrangle. The accumulations se far from continuous and there are grave doubts
to the contemporaneity of the individual deposits of either, since nothing has been seen which gives more than the most local indication of the position the ice margin.

The morainal deposits near Crooked Creek o unction of this creek with Tioga River and along the east side of the latter the stratified materials predominate. The morainal deposits of the latter
type appear in many instances to have formed after type appear in many instances to have formed after
the ice had become essentially motionless, and frequently grade into flat-topped morainal terraces built up in the more or less open spaces between
he ice and the valley walls. An important line of morainal deposits extends along Troups Creek of the Elkland quadrangle to the Tioga River, but is broken by a gap 8 miles in length between both till and stratified drift, the former, though not predominating, being in rather larger amounts
than in the majority of the morainal deposits of and possibly elsewhere. Morainic dams formerly
existed across Troups Creek a mile northwest of Knoxville, across the Cowanesque River east of Phillips, at the eastern edge of the Elkland quad-
rangle, and possibly also at Tompkins and elsewhere. Till deposits with drumloidal topography.-At everal points in the northeastern portion of the Tioga area and also on Elkhorn Creek in the same
quadrangle there are accumulations of till in the quadrangle there are accumulations of till in the
orm of small hills or slopes of drumloidal outline. In general these accumulations occur on the sides roughly parallel both with the valleys and with the probable direction of glacial movement. In all cases they are found in regions of thick drift and appear to be associated with typical morainal eposits, along which they occur in belts. Thei contrast with the irregular surfaces of the moraines. contrast with the irregular surfaces of the moraines.
The close association of the accumulations in question with the moraines, and the apparent intimate relation between the two kinds of deposits,
suggest that the small hills of drumloidal appearsuggest that the small hills of drumloidal appear-
ance are not the result of ordinary processes of ance are not the result of ordinary processes of
drumloidal accumulation taking place beneath the drumloidal accumulation taking place beneath the
ice sheet, but have very likely resulted from the ice sheet, but have very likely resulted from the
rounding action of overriding ice upon morainal ccumulations formed during some halt in the advance of the ice or during some earlier local or general recession of the ice sheet. It seems probable that some of the thick till deposits mentioned of the Tioga and Cowanesque rivers may be, in part at least, the overridden remnants of earlier moraines of the same general invasion.

Esker and kame deposits. - The eskers observed in the Elkland-Tioga area are two in number.
The first occurs in the extreme northeast corner of Lawrence Township, and is represented in the area covered by the map by a well-defined ridge about 25 feet in height and about half a mile in length.
The second is a few miles east of Mansfield, in The second is a few miles east of Mansfield, in
eastern Richmond Township and the northwest corner of Sullivan Township. At the east it begins as a well-defined ridge 15 or 20 feet in height, leading westward up a tributary of Elk Run. up into a series of kame deposits, which are interrupted at the crest, but soon begin again on the west side. A little farther down the westwardsloping valley the kame deposits narrow and
are succeeded by a single ridge some 20 feet in height, which continues with minor interruptions for a distance of three-fourths of a mile. The
eskers consist of fine to coarse gravels which were originally laid down by glacial streams flowing beneath or within or upon the surface of the ice heet, on the melting of which they were left as the g, narrow ridges described.

Each esker merges at its lower end with a contemporaneous series of morainal terraces, the
material of which was supplied by the stream which formed the esker. The deposition of the terrace evidently took place in open channels between t a stage of the ice sheet when all motion had (n)

The manner of replacement of the eskers at their the esker streams, though flowing between ice walls, were resting upon the valley bottoms at these points, were resting upon the valley bottoms at these points,
or at least very close to them. The conditions existing at other points in the esker streams, how-
ever, were not necessarily the same, and in the case of the esker stream east of Mansfield were certainly much more complex. In this instance the portion
of the stream east of the divide probably flowed upon the surface of the stagnant ice; at the divide
itself it appears to have flowed in an open channel itself it appears to have flowed in an open channel and to have cut a slight notch in the rock at the
crest; while west of the divide there was an open space from one-half to three-quarters of a mile in length, in which was deposited a flat-topped terrace. At the end of this space, at a distance of a little over a mile from the divide, the stream apparently
reentered the ice, and continued in it, probably in a tunnel at the bottom of the ice or in an open channel, until it finally emerged at the head of the extensive terraces bordering the north side of Corry Creek.

The kame deposits of the Elkland-Tioga area clude, besides the irregular gravel deposits mall deposits of confusedly stratified sands, gravels, 列., occurring in Chatham and Farmington townhips in the Elkland quadrangle. They are lieved to have been deposited in tunnels or other avities beneath the ice or in channels near the
margin into which flowed the waters derived from the basal portion of the ice sheet.

Morainal and frontal terraces.- By a frontal terrace is meant an approximately level-topped or ently sloping deposit of stratified drift which was between it and the slopes of the adjacent valley walls or hills. Such terraces differ from moraines that they have generally been deposited in adjacent slopes, or at least in prominent and welldefined streams flowing in similar positions along the margin of the ice. In consequence they are ainly of the nature of ordinary sedimentary beds, and in general exhibit morainal features only along ice-contact slopes.

The morainic aspect of the topography of the marginal or ice-contact slopes, is, however, fre-
quently a striking feature, and taken in connection ith the presence of occasional masses of till and bowlders has given rise to the variety of frontal terraces known u

Terraces of this type occur in the sides of all the valleys, and are especially well developed quadrangle, where the morainal character of the margins is unusually pronounced. In the Tioga area high flat-topped terraces occur south of the outh of Elkhorn Creek and southeast of Tioga unction. The former extends nearly across the fll width of the valley of Crooked Creek.

Where terraces occur on both sides of a valley they rarely possess the same elevation, having flowing on opposite sides of the residual ice tongues. owing on opposite sides of the residual ice tongues.
The slopes of the surfaces of the terraces usually correspond to the direction of the slopes of the
Dottoms of the containing valleys. An exception bottoms of the containing valleys. An exception
occurs in the case of the morainal terraces along the portions of Crooked Creek and Tioga River lying within the limits of the Tioga quadrangle. Terraces in these valleys rise in nearly every case an elevation of about 1180 feet, and were evi-
ently deposited in slack water, the level of which was determined by the height of the divide between Niles Valley and Stokesdale Junction in the Elkand quadrangle, over which the waters ponded in ont of the ice sheet lying across the Tioga River the north made their escape.

Glacial clays.-Clays of a buff or pinkish color tions have been noted in the beds or banks of everal of the streams entering the Tioga River from the west in the southern portion of the Tioga
quadrangle. They appear to have been deposited waters ponded in front of the ice margin at a time when it lay across the Tioga River to the
torth. The contortions (see fig. 8 on Illustration north. The contortions (see fig. 8 on Illustration lipping of the water-saturated clays at a period subsequent to the disappearance of the ice. Stratified valley drift.-In this class are included those depits of sand and gravel which everyhere underlie the flood-plain silts of the larger thickness of perhaps 80 to 90 feet or more, and are elieved to consist mainly of materials derived from the débris-laden basal portion of the ice sheet and rought together and deposited by the streams originating in the melting glacier and converging
in the main valleys. Occasional wells sunk for ater show that the deposits contain considerable mounts of unstratified drift, which at some points replaces the gravels. It also seems likely that in ome localities, at least, considerable additions were ce sheet, though at present deposition appears to 
fragments, deposited with only rude traces of strati-
fication, though occasionally showing rather distinct shingle structures (see fig. 8). They occur along the beds of streams of moderately steep grade, intermediate between the streams of high grade, the work of which is principally that of erosion, and the streams of very low grade, which are characterized by distinctly stratified deposits of well-rounded material of small size.

The gravel fans consist of similar materials which have been brought down by streams of all but the lowest grades and deposited in fan-shaped deltas at the points at which the velocity of the currents became checked on emerging upon the wide, flat bottoms of the river valleys.

The materials of both the stream and the fan deposits are much too coarse to be moved by the streams in their normal condition, and are transported or deposited only during unusual floods. They are still in active process of formation, a foot or more sometimes being added to some of the fans during a single flood. In most cases it seems probable that very little of the material of the fan mas la southward-leading valleys may be in part the result of deposition by glacial streams of which the valleys of deposition by glacial stien
were the lines of discharge.

Marsh deposits.-The marsh deposits of the ElkMarsh deposits.-The marsh deposits of the Elk-
land-Tioga area are of three types. The first is land-Tioga area are of three types. The first is
limited to the flood plains of the present rivers, the second to the broad, flat gravel or sand deposits of certain of the glacial streams. The marsh deposits occupying the abandoned channels of the Tioga and Cowanesque rivers, etc., though not represented on the map, are good examples of the former, while the extensive marshes at the headwaters of Crooked Creek, and probably also those south of Niles Valley and east of Marsh Creek in the Elkland quadrangle, are examples of the latter.

The third type of marsh deposits includes those occurring where the previously existing drainage has been obstructed by deposits of glacial drift. Marshes formed behind morainal or similar drift obstructions occur south of Elbridge in the Elkland quadrangle and in Charleston Township in the Tioga quadrangle, while small marshes formed in shallow basins in the till sheet are found at a con-
siderable number of points, especially in the northastern portion of the Tioga are

Flood-plain silts. - The flood-plain silts consist of fine sediments, practically free from pebbles, which have been deposited as a mantle several feet in thickness over the top of the thick glacial and recent gravels which constitute the greater portion of the filling in the bottoms of the larger valleys. They are still in process of formation, receiving new though slight additions at every overflow of the streams.

\section{GEOLOGIC STRUCTURF}

The Elkland and Tioga quadrangles belong to the moderately folded western division of the Appalachian province as described on page 1 under "Gen-
eral relations"- - the part lying west and northwest eral relations"- the part lying west and northwest
of the Allegheny Front, the western margin of the Appalachian Valley. Westward from the Allegheny Front the folding gradually becomes less pronounced, and finally subsides into the very gently undulating or almost flat structure of southern New York and northwestern Pennsylvania.

The quadrangles under consideration are situated about 40 miles from the Allegheny Front, and are characterized by gentle though distinct folding. The dips throughout the greater part of the area The dips throughout the greater part of the area
are very gentle, being as a rule hardly appreciable are very gentle, being as a rule hardly appreciable torger exposures, however, the rocks are seen to possess gentle inclinations, usually from $2^{\circ}$ to $4^{\circ}$, in a few instances dips as high as $15^{\circ}$ or $20^{\circ}$ were
noted. These dips, slight as they are, are suffinoted. These dips, slight as they are, are sufficient, nevertheless, to make a difference of about 2500 feet between the altitude at which beds occur at the bottoms of the deeper synclines and that at which they occur at the crest of the higher anticline

The area is crossed by two synclines and two anticlines, which, beginning at the north, may be designated the Cowanesque syncline, the SabinsWellsboro anticline. The structure of the folds and the relations they bear to one another are
slank they appear to vary from 700 to 900 feet,
though considerably greater dips may occur locally. give at 100-foot intervals the elevation of the Pine Creek syncline.-The Pine Creek syncline wpper surface of the Chemung formation in its is named from Pine Creek, a prominent strean clation to sea level. In the anticlinal areas where which flows for a considerable distance along the the top of the Chemung has been eroded the eleva- south flank of the syncline before it finally turn

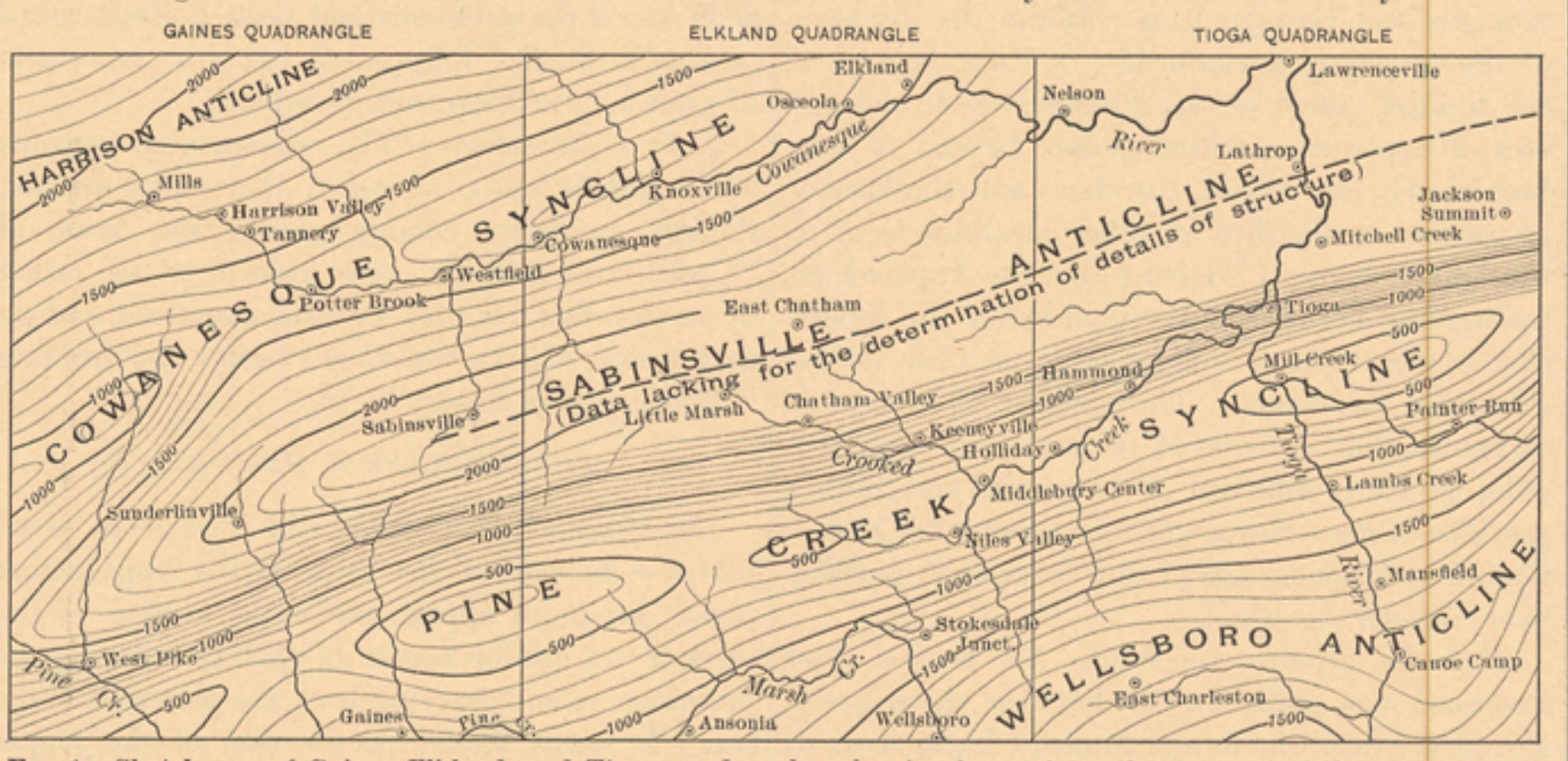
FIG. 1.-Sketeh map of Gaines, Elkland, and Tioga quadrangles, showing by

ossess if no erosion had taken place. Occasional reference to the figure, in connection with the following descriptions, will give a clearer understand-
ing of the points described. Fig. 4 , on page ing of the points described. Fig. 4, on page
, shows the extension of the folds in both directions and brings out more plainly the relations of the structure of the area to that of Cons of the Allegheny Plateau.

Cowanesque syncline.-The Cowanesque syncline kes its name from the Cowanesque River, which line enters its axis from the point where the synto the point where it leaves the area a little northwest of the village of Elkland. The syncline is leepest near Knoxville, from which it shallows very gradually in both directions.
.

The rocks of the Chemung formation are exposed in the valleys along the axis of the syncline at all points except near the western edge of the quad-
rangle, and even here they appear in the side valeys within a distance of a mile or so from its axis. Higher up the hills are composed of rocks of the Cattaraugus formation, a few of the higher crests even

The dips of the beds toward the axis of the syncline are gentle, amounting to about 200 feet per mile on the north side and from 150 to 300 feet per mile on the south side, the gre

Sabinsville anticline.-This anticline is named from the village of Sabinsville, in Clymer Township, about $1 \frac{1}{2}$ miles west of the western boundary of the Elkland quadrangle and near the summit of the anticline. The axis enters the quadrangle a little to the south of the north line of Clymer Township, passes north of Little Marsh and south of East Chatham, and leaves it at a point east and a
little south of Elbridge. From this point it extends northeastward into the Tioga quadrangle, crossing the Tioga River near Rising, and leaving the quadrangle a

The anticline is highest where it leaves the area at the east, though the greatest thickness exposed is probably along the deep cut of the Tioga River, whe brought to the surface by the anticline. To the west the axis pitches gradually downward the rate of 50 feet or less per mile until it passes ut of the area at the western edge of the Elkland quadrangle. Only 500 feet or so of rocks are here exposed.

In the Tioga quadrangle the Chemung sediments constitute the surface rocks over the entire area of the anticline, but in the Elkland quadrangle occasional patches of Cattaraugus beds cap the hills on the northern flank. The width of the Chemung Delt on the uplands at the western limits of the but it rapidly increases until at the eastern edge of 7 miles.

The dips on the north flank of the anticline vary point just south of Ansonia and near the southern limits of the Elkland quadrangle. The axis enters
the Elkland quadrangle near the head of Big Asaph Run, and extends across it with a course about $\mathrm{N} .75^{\circ} \mathrm{E}$. It passes from the Elkland to the Tioga quadrangle near the point where Crooked Creek enters the latter, and continues with a similar course to the eastern edge of the quadrangle at a It crosses Tioga River a little south of the mouth Mill Creek.

The syncline reaches its greatest depth at the western edge of the Elkland quadrangle, where a few feet of the sandstones above the conglomerate occur. To the east the conglomerate caps the lower and the conglomerate is absent. East of the river, however, it deepens again and the conglomate caps the crest west of Painter Run.

The rise of the beds to the north, as has bee seen from the description of the Sabinsville anticline, ordinarily varies from 700 to 900 feet per mile. To the south the rise is much
varying from 150 to 300 feet per mile.

Wellsboro anticline.-This anticline takes ame from the town of Wellsboro, the county seat of Tioga County, which is located on the nort flank of the fold. The axis crosses the Elklan quadrangle at its extreme southeast corner and enters the Tioga quadrangle a little south of
Charleston. At this point it has a bearing about N. $35^{\circ}$ E., but it gradually swings to the little south of east. East of Canoe Camp, how-
ver, it bends sharply to the north, and it passes ever, it bends sharply to the north, and it passes
out of the quadrangle with a course approximately N. $45^{\circ}$ E., at a point 4 miles east and between $1 \frac{1}{2}$ nd 2 miles north of Mansfield. to about 300 feet per mile, appear to occur near the quadrangle, and near the eastern edge of the latter in the vicinity of the junction of Elk Run and Mill Creek. The gentlest of the northerly dips occur near the Tioga River, where the beds slope erly dips are more gentle, being on an average from 100 to 150 feet per mile. The steepest occur at the broad, flat swell of the anticline in the vicinity Canoe Camp and Canoe Camp Creek. Section sheet supplement the above description by
showing in a graphic manner the probable underground extensions of the beds recognized at the surface. They show the relative positions of the beds and the folds into which they have been compressed, as they would be exhibited if cut transat the upper edge of the blank space above the section on the map. The horizontal and vertical and dips the same; hence the hills, the thicknes the folds, are shown in the proportions in which they actually occur. In the absence of deep wells, crests for a distance of about $7 \frac{1}{2}$ miles. Between ast and south until near the Tioga River it bears

The steepest of the northerly dips, amounting

Structure sections.-The sections on the Structure or other underground sources of information, the
structure beneath the ground has been inferred from what it was possible to observe on the surface.

\section{GEOLOGIC HISTORY.}

AOOUMULATION OF THE LOCAL SEDIMENTS. DEVONIAN DEPOSTTS.

Chemung deposition.-The earliest deposits which appear at the surface in the Elkland and Tioga quadrangles are the fossiliferous sandstones, shales, and thin limestones of the Chemung formation. At the time these beds were deposited, namely, near the close of the Devonian period, nearly the whole of the southern half of the interior portion of what by the the North American continent was covered by the waters of a great interior sea, which, however, the far north and also at times with the present Gulf of Mexico. It was in a great bay of this sea which extended across western and central Pennsylvania and southern New York that the deposits of the Chemung were laid down. The land from which the sediments were derived was situate to the east of the present Appalachian Mountains,
the highest points in the northern portion of the province being probably not far from the present province being probably not far from the present
coast line of the Atlantic. To the south the Devonian land is known to have been low and flat,
Devoning of the Atlantic. To the south the and it seems likely that in the north the relief was ikewise rather moderate.

The waters of the bay in which the deposition took place were comparatively shallow, as is sediments the somewhat sandy character of the and cross bedding resulting from the action of currents of some strength. That the water in the Pennsylvania and New York region was clear and salt, and not fresh or brackish, or charged with silt, as was the case during the same period farther as was the case during the same period farther
south, and also in the north during the deposition of a considerable portion of the overlying Cattaraugus and Oswayo formations, is attested by the presence of an especially abundant marine fauna. A characteristic feature of the Chemung formation is the great number of alternations of
material which it exhibits. It is true there are no material which it exhibits. It is true there are no
indications of marked or extensive changes of conindications of marked or extensive changes of condition; but the rapid alternations of the thin beds of shales and sandstones, with occasional thin limestones, are indicative of fluctuations great enough to affect deposition, though probably the changes were mainly of a local nature. These rapid changes in the northern areas were again at variance with fairly constant during the corresponding period of time

CATSKILL-Pocono Group.
Cattaraugus and Oswayo deposition.-The deposition of the Cattaraugus beds was preceded or accompanied by a somewhat marked change of physical conditions. The salt-water deposits of the Chemung gave place, as attested by ferns, freshwater fishes, etc., to the fresh- or brackish-water deposits of the Cattaraugus formation. The waters at the same time doubtless became much shallower, cross bedding, ripple marks, rain prints, and other shore features, apparently indicating a more or less complete separation

Whether this change was brought about by a Whether this change was brought about by of subsidence which had been going on during the deposition of the Chemung and earlier sediments, or by the rapid accumulation of the sediments hemselves, resulting from an increased rate of erosion due to an increase in the elevation of the land area, is not fully understood. It is known,
however, that the deposition which marks the however, that the deposition which marks the advent of what are usually known as Catskill conditions did not take place at the same time throughout the areal extent of the formation, but was earliest in the eastern portion of the embayment and became progressively later as the distance from York the deposition of the In eastern New believed to have begun just after the close of the Hamilton, and as time elansed and the condi-

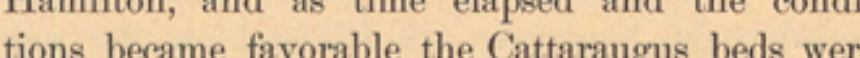
Elkland and Tioga. 
deposited farther and farther west. It was probably not until near or possibly after the close of the Devonian, however, that conditions favorable to the deposition of red beds came into existence in western New York. In the Elkland-Tioga region the Catskill conditions were inaugurated after 2000 feet or more of Chemung sediments had been deposited, and continued at least to the close of the Devonian, and probably well into the CarboniferDevonian, a d
ous period.

Fluctuations of the conditions of deposition were probably less frequent during the deposition of the Catskill-Pocono group than in the Che mung. This is indicated by the less frequen changes in lithologic character in the former group,
and the greater thickness of the component strata. The greater thickness, however, may have resulted entirely from greater rapidity of deposition in the Catskill-Pocono group, due to the fact that the accumulation took place close to the shores of The supply of material was also probably greate because of acceleration of land erosion due to the slight uplift which appears to have accompanied the inauguration of Catskill conditions.

The red Cattaraugus shales, which are the earliest of the deposits accompanying the introappear, the sandstones at the same time rapidly appear, the sandstones at the same time rapidly
increasing in importance and constituting the sandy formation known as the Oswayo. The change from formation known as the Oswayo. The change from
one to another, however, takes place without recognizable break, indicating the absence of any
abrupt change of conditions at the opening of the abrupt change of con
Carboniferous period.

$$
\text { CARBONIFEROUS DEPOSITS. }
$$

Mauch Chunk deposition.-Following the deposition of the Oswayo sandstones, which carry relatively little shale, there appears to have been a
return to conditions similar to those existing during return to conditions similar to those existing during
the accumulation of the deposits of the Catskill type. As in the case of the Catskill deposits, the sediments were thickest in the east, and decreased gradually from a maximum of about 3000 feet in the region of the anthracite fields of Pennsylvania to nothing in the northwestern part of the State. To the east the sediments were evidently deposited and green shale, also include considerable thicknesses of sray, alroenish, buff, considerable thicknesses of gray, greenish, buff, and even carbon-
iferous sandstones. To the west the series is less sandy and the shales become distinctly calacareous and include thin beds of impure limestone, apparently indicating deeper-water conditions. In the region about Gaines the red and green shales corresponding in position to the Mauch Chunk are not over 40 feet in thickness at the most, and are not over 40 feet in thic

Pre-Pottsville deform have been followed by a period in which deposition ceased and the clays just laid in which deposition less extensively eroded. In the Elkland-Tioga region the Mauch Chunk beds have been recognized only in occasional patches, and the entire lower and middle portions of the Pottsville formation are missing, the Sharon conglomerate, constituting the lowermost member of the upper division of the Pottsville, resting either on the Mauch Chunk shales or on the Oswayo sandstones.

Two hypotheses have been advanced to account for the absence of the lower and middle Pottsville deposits and the erosion of the Mauch Chunk shales. The first postulates strong currents sweeping around the borders of the embayment from the southwest and receiving and partially distributing sediments from the land on the southeast and east. No sediments are supposed to have been received
from the north, the action of the currents on the from the north, the action of the currents on the
north side of the embayment being almost entirely one of scour. The second hypothesis postulates a
bodily uplift of the region, bringing all but the bodily uplift of the region, bringing all but the
southern and eastern portions of the floor of the former embayment above the level of the waters, where it was subjected to erosion by streams or

The uplift, which is here considered as the more probable cause of the Mauch Chunk-Pottsville unconformity, is generally supposed to have taken place without noticeable folding. In the Gaines quadrangle, bordering the Elkland on the west, however, there are phenomena which appear to indi-
cate that this suggestion is not correct. Thus, in the region about Gaines and Gurnee, in the southeastern portion of the Gaines quadrangle, it was foun that the dips of the Pottsville conglomerate were
the only from a third to half as great as the calculated dips of the Chemung and the conformable Cattaraugus and Oswayo beds. While the existence
of the structural unconformity can not, because of the limited extent of the Pottsville beds and the lack of exposure at critical points, be said to have been clearly established, the above and similar discrepancies in the dips at other localities seem to bear out the natural inference that the Appalachian folding had begun in this region before the deposition of the Sharon conglomerate member of the Pottsville formation. The amount of erosion unknown, but is believed to have been considerable; probably sufficient in the western and thinner portions of the series to entirely remove the Mauch ver considerable areas.

Potsville deposition.-While the erosion just sibsidence near the former absidence near the former Mauch Chunk shore isting of materials derived from the adjoinin Archean lands, were laid down. It was considerably later when the subsidence, which once more carried the eroded surface of the Mauch Chunk
chen beds below the level of the sea, extended to the western portion of the State. The Sharon con-
glomerate, constituting in the Gaines region the glomerate, constituting in the Gaines region the
lowest of the Pottsville beds, and known from the paleobotanical evidence of the associated sandstone to belong to the upper division of the Pottsville, did not begin to be deposited until after many hundred feet of Pottsville sedi

After the deposition of the Sharon conglonerate the conditions during the deposition of the remainder of the Pottsville sediments were somewhat unsettled. Periods of submergence, marked y the deposition of sandstones, alternated wit eriods of slight uplift, during which considerable areas were cut off from the sea, and fresh-water
vegetation, now marked by the black shale and coal egetation, now marked by the black shale and coa
beds, flourished upon their surfaces. These alterbeds, flourished upon their surfaces. These alternatle, and in fact throughout the remainder of the
vilng ville, and in fact throughout the remainder of the
Carboniferous period, during which many hundred tet of sandstones, shales, limestones, etc., were lai down.

\section{UPLIFT AND FOLDING.}

Appalachian revolution.-The deposition of the thick sediments of the Carboniferous was accom-
panied by a gradual subsidence of the sea bottom; panied by a gradual subsidence of the sea bottom
a process which is essential to the accumulation of great thicknesses of strata, since otherwise the sea basin would soon

The depression thus inaugurated constituted zone of weakness, and under the application of broad and often steep folds and broken by the great fractures or faults which are so characteristic of the Appalachian province. The beginning of the folding, if the interpretation of the conditions of unconformity near Gaines is correct, began as early as the close of the deposition of the Mauch Chunk beds, but it did not attain its maximum
until near the close of the Carboniferous period. The extent and complexity of the folding and
The faulting are greatest in the east, or near the coast line of the interior sea. It was here, in close prox-
imity to the shore, that the sediments accumulated in greatest thickness, that the subsidence and weakening of the crust were greatest, and that, consequently, the effect of lateral or tangential pressure Appalachian province the difference in elevatio between the crests and troughs of the folds is often several thousand feet, and the faults are of great length and magnitude. To the west and north the Sharp folds give place to the open folds and gentle undulations of the western portion of the province; undulations of the western portion of the province;
faulting becomes less frequent, and finally ceases almost entirely. It is in this gently folded region almost entirely. It is in this gently
that the Elkland and Tioga areas lie.

Accompanying the development of the folds of the Appalachian region, constituting what is known | higher and the lower of the apparent surfaces to s the Appalachian revolution, there was a gener the result of which was to lift its surface above the water and to bring to a close the history of this great interior sea. At the same time it is believe that there was a sinking of the eastern land mas from which the sediments had been derived, until most of it finally disappeared benea
of what is now the Atlantic Ocean.

\section{Later deformations. - The subsequ}

of the earth's crust, of which there were several though properly coming under the head of by erosion features than by rock structures, and for that reason will be considered under the heading "Physiographic history."

PHYSIOGRAPHIC HISTORY

Development of Triassic and Cretaceous pene-
pains.-As soon as the folds of the Appalachian plains.-As soon as the folds of the Appalachian
region began to appear above the surface of the interior sea, erosion began its work of reducing the prominences and carrying back the materials to the
sea. It seems likely, in the case of the Appasea. It seems likely, in the case of the Appa-
lachian Mountains, that erosion did not keep lachian Mountains, that erosion did not keep
pace with the uplifting of the folds, but that more or less pronounced elevations soon began to appear
and to increase in prominence as long as the foldand to increase in prominence as long as the fold-
ing continued. After the cessation of the folding the land is believed to have remained fairly constant in elevation during the remainder of the Carboniferous and early Triassic times. In this interval erosion progressed rapidly, though to exactly what extent is not established. It is known, however, that the Newark beds of later Triassic border, rest upon rocks reduced by erosion to a flat or gently rolling surface, known to geologists as peneplain.

The uplift, accompanied by the tilting and faultJurassic times, partly beds in late Triassic or early Jurassic times, partly destroyed the effect of pre-
vious erosion. Erosion in the new cycle proceeded vigorously, with the result that the continental

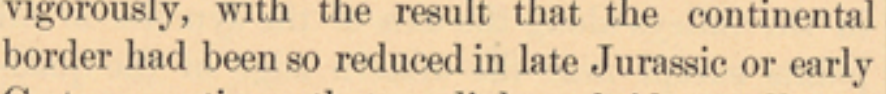
Cretaceous times that a slight subsidence allowed
the sea to advance and cover with deposits of Crethe sea to advance and cover with deposits of Cre-
taceous age the wide, flat or undulating lowlands taceous age the wide, flat or undulating lowlands
reaching to the base of the highlands then existing near the present limits of the coastal plain. Erosion, however, continued its attack on the remain-
ing highlands with undiminished energy until in late Cretaceous times they had been reduced to a peneplain - the Cretaceous peneplain - on which the folds of the Appalachian region were reprecomponent strata, both hard and soft, and of all ages, being alike cut down to the peneplain level. The highest point of this peneplain, in the north at least, is supposed, on the ground of drainage indications, to have been in northern Pennsylvania or probably sloped away in all directions. An idea probably sloped away in all directions. An idea
of the nature of the peneplain surface may still be obtained from the top of one of the flat-topped
ond mountain crests. Viewed from such a standpoint, to reach the same general level, and the irregularities, which when seen close at hand sometimes seem to be important, appear in their true nature
when viewed from a distance-as simply slight when viewed from a distance-as simply slight
undulations in the upland surface. All except the nearest of the valleys, though perhaps a thousand feet deep, disappear from view, and one apparently looks out over a very gently undulating, almost
featureless plain covered with forests. This apparent plain is probably a close reproduction of the ppearance of the original plain before the erosive action of the stream had begun to cut into it, and to wear it away until only the flat-topped ridges old land surface.

\section{Early Tertiary}

he topography of theplain.-In the description of he topography of the Elkland-Tioga region it was shown that there are evidences of the existence of
old surfaces at two distinct elevations, the higher ne marked by the flat-topped crests of the mounthin belts and the lower by the higher of the hills are two explanations by which these features may are two explanations by which these features may
be accounted for. The first assumes both the

have been contemporaneous in development, and to represent the limits of variation of a single surface, while the second explanation assumes that only the upper level, marked by the mountain crests, is to be correlated with the Cretaceous pene-
plain, the lower level being referred to an early Tertiary, possibly Eocene, period of local peneplanation

The objection to referring the two apparent levels to a single surface lies in the fact that the range of elevation, amounting to from 200 to 400 feet, indiin incomplete peneplanation not in harmony (he opped mountain surface presented in the tatwhich has been urged against the Creta f the general surface of the region is its atively youthful aspect. Notwithstanding the very moderate resistance of the rocks of the region to erosion, considerable remnants of the old peneplain surface are preserved practically without plain surface are preserved practically without
modification, while, except in the areas of the ofter Chemung shales, the valleys are still sharp and $\mathbf{V}$-shaped.

The topography of the area, as shown in the discussion of the relief, appears to point to a southastward slope of the supposed lower peneplain level at a rate of about 200 feet in the length of the quadrangle. No accurate maps exist covering an qua equivalent to four quadrangles lying to the forks of the Susquehanna, there are evidences of a former rather well-defined surface developed on the softer rocks at a level of about 900 feet. This elevation accords well with the assumed southeastern slope of the supposed early Tertiary peneplain. In the next two quadrangles to the south plain. In the next two quadrangles to the south
the slope continues, with increased grade, until in the neighborhood of Harrisburg it has a level of bout 500 feet.

The evidence, therefore, so far as it goes, point to the probable existence in the Elkland-Tioga
region of remnants of two peneplains, an peneplain of Cretaceous age and a lower peneplai apparently to be correlated with the peneplain
developed on the softer belts on each side of the usquehanna in early Tertiary time.

The vertical interval between the upper and the lower peneplains varies from about 400 feet in the Elkland-Tioga area to 1100 feet in the vicinity of Harrisburg, and probably about 1200 feet in the indicate that previous to the last prominent uplift the remnants of the Cretaceous peneplain stood at an altitude of about 1100 feet above the later than 400 feet above it in the Elkland-Tioga region. What the altitude may have been relative to sea level can not be told, but it is probable that it was not much in excess of the figures indicated. The 
streams of the newly folded regions must have of Chemung rocks, as a completely adjusted systen would have done, but usually took an intermediate position at one side of the hard rocks oceupying he center of the syncline. In some instances, however, such as those of the Cowanesque River and the stream draining the Blossburg syncline (see fig. 4), the drainage was consequent, the streams flowing for some distance along the very center of the synclines. To what extent the courses of the transverse streams have been influenced by the outcrops of the folded beds is not apparent, though it seems probable that in the Elkland-Tioga region the influence has been very slight. In fact, although in its broader relations the development of the present drainage appears to have been of the present drainage appears to have been
dependent to a considerable extent upon the geologic structure, its minor features show very little logic structure,

The present drainage lines, coinciding as they do with those which existed on the surface of the older peneplain, may be said to have been inherited from that surface. Further back than that, little is known beyond the existence of the general relationship of the drainage to structure.

Uplifting and erosion of later peneplain_-After the development of the lower and younger of the peneplains, the completion of which is assigned provisionally to early Tertiary times, possibly Eocene, there occurred an uplift, accompanied by tilting and slight warping, which elevated the surface to a position not far from that which its face to a position not far from that which its
uneroded remnants still occupy. The result was an increased activity of the streams, which began the cutting of deep and canyon-like gorges, first in their lower courses and later nearer their headwaters. This erosion, though affected by a number of oscillations of level in late Tertiary or Pleistocene times, has continued until the present, and has produced the topography which now exists. The uplift which inaugurated this period of erosion appears to have culminated at a point some distance northwest of the Elkland-Tioga area reet 11 and 12 feet pile tilting appear to have been sufficient to The tilting appears to have been sufficient to change the general slope of the peneplain from a north-
eastward direction, as indicated by its drainage lines, to a southeastward direction, but the uplift was not rapid enough to reverse the drainage. In act, the effect of the southward slope is shown chiefly in the greater activity of the southwardflowing streams, as recorded by their greater length and their greater erosive effects. This relationship of length to direction of flow is well brought out at several points in the surrounding region (see fig. 4), but is not conspicuous in the Elkland-Tioga area itself.

Later Tertiary events.-It has been frequently urged among geologists that the advent of the earliest Pleistocene ice sheet was preceded by a general uplift of the northern half of the continent, affecting the surface throughout the northern portion of the United States. In western Pennsylvania, however, the presence of Pleistocene river gravels on ever, the presence of Pleistocene river gravels on of the present gorge of the Upper Allegheny River indicates that the last stage of active erosion did not begin there until after the first ice invasion, though the uplift and the inauguration of the erosion in the lower reaches of the river may have
been somewhat earlier. The uplift recorded by the rock terraces immediately adjacent to the Susquehanna in the eastern portion of the State is of questionable date, but would appear to be of late Tertiary or early Pleistocene age.

In the Elkland-Tioga region there appears to be a slight notching in the bottom of the old valley of Pine Creek and some of its tributaries, but it is believed that this was not produced until after the southward deflection of the lower portion of the creek through the gorge south of Ansonia. This diversion, as will be described more fully in the discussion of the earliest glacial stage, was probdiscussion of the earliest glacial stage, was proboverflow of waters ponded in front of the advancoverflow of waters ponded in front of the advanc-
ing ice sheet, and the consequent reduction of the ing ice sheet, and the consequent reduction of the
divides and the cutting of a new channel in which divides and the cutting of a new channel in which
the stream persisted even after the ice had disapthe stream persisted even after the ice had disappeared. The notching of the bottom of Pine Elkland and Tioga. GLAOLAL HISTORY From the phenomena of erosion, transportation, drifts is shown in fig. 2. cated with glacial action, it has been established that $\quad$ KANSAN OR PRE-KANSAN INVASIO idvance of the ice.-The cause of the accumu(Pleistocene) geo- lation of the glacial ice and its spread over so large now covering the greater part of Greenland. The phenomena associated with the ice invasion an ice sheet came into existence in the norther

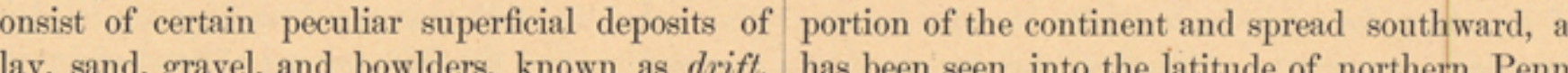
nd certain scourings and groovings of the surface sylvania (see fig. 2).

of the underlying rocks, evidently due to some Obstruction and defection of drainage - When gent like a glacier furnished with rock fragments the ice margin advancing from the northea which were pushed or dragged along over the sur- reached the lower portion of the Tioga River nea face upon which it rested. The examination of Corning, N. Y., the natural outlet for the water these deposits over the vast area covered by the ice of that river and its tributaries, draining the
leaves no reasonable doubt that this was their gen- Elkland-Tioga area and the whole of the northern ral mode of origin, though parts of the material, and eastern portions of Tioga County, was is equally clear, were deposited through the obstructed, and a series of long, narrow lakes simiagency of glacial waters. The two types unite to lar to the Finger Lakes of New York, but more form a nearly continuous mantle, indiscriminately ges.

Tioked, came into existence in the valleys of the these branching lakes tributaries. The water in Glacial stages.-While the fact is not usually
until it finally overflowed at the lowest divide and
passed off to the south into the Susquehanna. detailed examination of its structure and of its gen- The lowest divide appears to have been about 2 ral distribution and associations shows that instead miles south of Ansonia. Its elevation can not now f a single sheet formed by one ice advance there be determined, but it had probably undergone $\begin{array}{ll}\begin{array}{ll}\text { re in reality several distinct drift sheets, each of } \\ \text { which represents a separate ice advance. }\end{array} & \text { great redion by the backward cutting of the } \\ \text { headwaters of the southward-leading stream in con }\end{array}$ The intervals of deglaciation or disappearance of sequence of the uplift and tilting of the Tertiary ice between these ice advances are made apparent
by the presence of soils and beds of peat and marl nd other effects of the continued advance of the ice the ing of certain zones now buried in the midst of esque River, the arm of the early lake occupyin rift deposits; while the sheets themselves differ its valley became a separate lake, which continue markedly in extent and often in color, composition, to rise until it found a divide at the head of
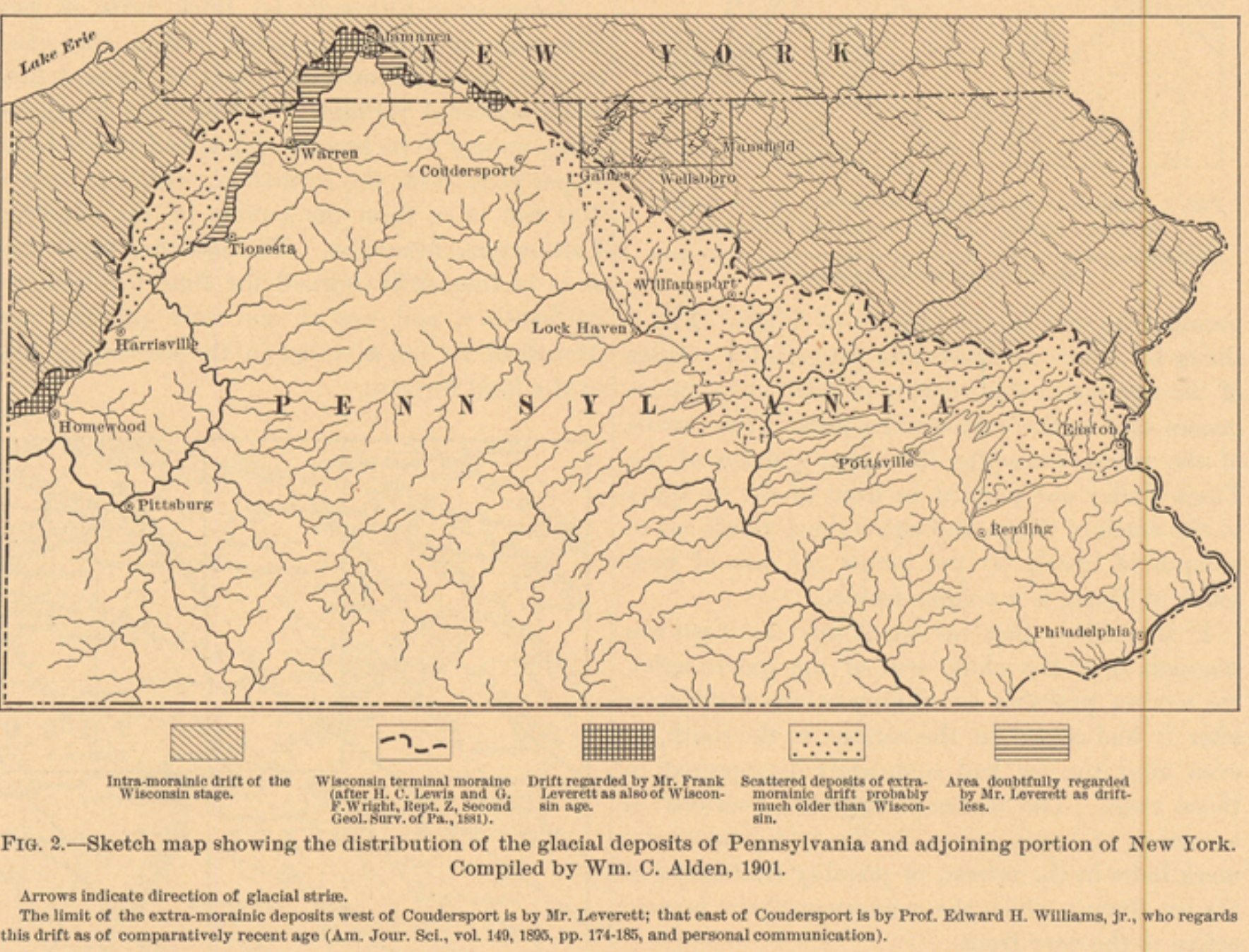

nd other physical properties. These differences, Jemason Creek, 3 or 4 miles east of the wester ogether with the morainal ridges marking the limits of the Elkland quadrangle. The elevation various positions of the ice margins, form a basis appears to have been originally 1600 or 1700 feet, fle Glacial epoch in North into divisions, as follows:

Outline of Glacial stages.

1. Pre-Kansan or sub-Aftonian glaciation-
2. Attonian deglaciation.
3. Kansan glaciation.
4. Yarmouth deglaciation.
5. Illinoian glaciation.
6. Sangamon deglaciation.
7. Iowan glaciation.
8. Peorian deglaciation.
9. Wisconsin glaciation (latest stage).

Of the drift sheets of the various stages described, only two have been recognized in Pennsylvania, and of these only one can be assigned with certainty
to a definite stage. This is the main drift sheet to a definite stage. This is the main drift sheet
covering the northern part of the State and including the Elkland and Tioga quadrangles. It is ssigned to the Wisconsin stage. The other recog-
ized drift consists of scattered fragments or a thi but it was gradually reduced as the waters continued to pour over its crest. On the closing of this outlet by the advancing ice a new one was more over the divide between Mill Creek and Lon Run in central Clymer Township, about 3 miles west of the limits of the Elkland quadrangle. This in turn continued to suffer reduction by the escaping waters until the advancing ice covered the region and brought the first chapter of the history of the lakes to an end.

Drift deposits.-So thin is the early drift sheet in this part of Pennsylvania that it is only rarely that any direct glacial deposits of the early stage, even a few feet thick, are to be observed, and over a
large area an occasional ice-transported fragment large area an occasional ice-transported fragment
from the north is all that there is to indicate th from the north is all that there is to indicate the former presence of the ice. It seems likely, from the first invasion remained but a short time in the 1 some cases at least, by the irregular movements of have been brought from the north and deposite by the ice; though the alternative view that the and have since been materially reduced by erosion is maintained by some.

The thinness of this drift has also made it very difficult to determine the exact limits of the first ice invasion, though it seems probable that it the Elkland-Tioga area. North of the southern limits of the Wisconsin advance, the effects are still more obscured because of the deposits of that invasion, and so far as can be seen at the surface the glacial phenomena appear to have been the work solely of the latter invasion.

INTERVAL OF DEGLACIATION.

With the cessation of the conditions favorable to the existence of the ice sheet the latter drew back to the north and possibly quite disappeared from the continent. During this retreat it is probable that series of events took place similar to those which occurred during the advance, but in akes were of shorter duration than the earlier ones, and that the divides over which the waters escaped uffered relatively little reduction at that time. The character of the topography of the divide south of Ansonia is such that it appears probable that its origin antedates the Wisconsin stage, and it seems likely that the reduction had proceeded so far at the close of the Kansan stage that the pass of upper Pine Creek.

Upon the disappearance of the ice sheet, stream and the atmosphere began their work on the glacial deposits, and in some parts of Pennsylvania even on the underlying rocks, with the result that drift as remained was deeply weathered and leached of its calcareous constituents. This weathering is integrated crystalline fragments, and is in marked contrast with that of similar fragments in the Wisconsin drift, which show almost no evidence of decay. The disintegrated and decayed state of the materials of this early drift indicates a long exposure to the weather, and taken in connection with occurred in many places since their deposition, has
led most geologists to believe that the time interval between their deposition and that of the Wisconsin drift is many times as long as that which has
elapsed since the latter drift was laid down. The elapsed since the latter drift was laid down. The
long intervening time was marked, farther north at least, by stages of glaciation, when the ice drift deposits, and by intervals of deglaciation, when the ice retreated far to the north, or even completely disappeared. None of these advances the Wisconsin drift in the Pennsylvania region.

Advance of the ice.-The recurring condition favorable to glaciation at length produced an ice heet during the Wisconsin stage which, starting in the north, spread southward and reached well
into Pennsylvania. The limits of this invasion are hown on the sketch map of Pennsylvania (fig. 2). Direction of ice movement. - As in the earlier invasion, the general movement of the ice was from the northeast toward the southwest (fig. 2). The local movement, however, was probably more or less over which the ice passed, and varied from S. $10^{\circ} \mathrm{W}$. to due west. The location and direction of observed triæ are shown on the Surficial Geology maps. Across the flat uplands, as west of the head of Baldwin Run in the Elkland quadrangle, the direction of movement was only about $10^{\circ}$ from due

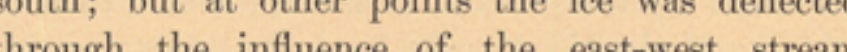
valleys until in some cases the ice movement was nearly due west. Such valleys had a maximum influence on the ice motion during the opening and elatively thin, and a minimum influence when the afforded even then the easiest outlet for the water the extensive erosion which is known to have losing stages of the invasion, when the sheet wa 
loose materials set free beneath the ice sheet by detail for the Elkland-Tioga region and vicinity. basal melting during the closing stages of glacial

Deflection of drainage. - When the ice margin advancing from the northeast obstructed the lower portion of the Tioga River near Corning, N. Y., the drainage of the Elkland-Tioga area was again gathered into long, narrow lakes which found an outlet, as in the earlier invasion, just south of obstructed the course of the Cowanesque River the drainage of this stream was likewise foreed to seek a new outlet, in this case across the divide between the headwaters of Jemason and Crooked creeks in Chatham Township. Still later Jemason Creek was itself obstructed by the ice, the waters of the upper portion of the Cowanesque finding an outlet upper portion of the Cowanesque finding an outlet

of the limits of the Elkland quadrangle.

No very prominent deflections of drainag headwaters of Hills Creek, in Charleston Township, headwaters of Hills Creek, in Charleston Township, were turned to the southwest and, after cutting sharp channels through two divides (designated glacial spillways on the Surficial Geology maps), eventually emptied into the headwate

Catlin Hollow stream near Charleston.

Work of the glacier.-The work of the glacier consisted in the erosion of the surface of the rock over which it moved, the transportation of the from the places derivation, and the deposition from the places of derivation, and the deposition of his débris, both directly by the melting ice and indirectly by the waters flowing beneath the glacier or issuing from its front. The amount and char-
acter of the work accomplished by the ice in a given locality depended largely upon its thickness and rapidity of movement, upon the amount of abrasive materials which it held, and upon the character of the rock over which it moved.

In the Elkland-Tioga area all the broader topographic features are clearly the work of streams, hough the ice was possibly an important facto in producing the beautifully flowing contours of the broad areas of Chemung rocks. That the action of erosion was not a powerful one, however, is apparent on passing into the areas of the harder
Cattaraugus and Oswayo formations, where the slopes are steep, the crests imperfectly rounded and nearly free from glacial deposits, and projecting ledges abundant. An examination of the rounded Chemung hills shows that a very slight cutting casually serves to expose the underlying rock, indito coatings of glacial materials. In fact, the to eoatings of glacial materials. In fact, the
general topography is everywhere manifestly the general topography is everywhere manifestly the
result of stream erosion. Although in general the result of stream erosion. Although in general the
glacial action was not such as would produce an glacial action was not such as would produce an
important modification of the topography, there were local conditions, especially in certain of the valleys, which favored the accumulation of considerable amounts of glacial drift. Entering into the deep, narrow valleys transverse to the direction of glacial movement, the heavily drift-laden basal layers of the ice sheet became lodged, or at least greatly or through the agency of the glacial waters which were concentrated in the valleys, the quantities of drift found in such positions.

The most conspicuous deposits of the glacier, however, are those which accumulated in the however, are those which accumulated in the
manner previously described at the immediate margin of the ice and which are known as the margin of the ice and which are known as the every important halt in the advance and the retreat of the ice. Those formed under the former conditions would usually be removed or at least undergo important modifications by the ice during its maxi-
mum development. The hills of drumloidal appearance in the northeastern portion of the Tiog area have been qualifiedly referred to such early morainal deposits which were later overriden and rounded by the ice, and it seems possible that the thicker of the till deposits banked against the sides of the Tioga and Cowanesque valleys may hav had a similar origin.

The outermost or terminal moraine, though nowhere touching these quadrangles, is of special interest as marking, in this region at least, the farthest advance of the ice of the Wisconsin invagion did not respond quickly to this climatic ems likely that it had ceased in some cases whil of Tioga during the final retreat of the ice.
Ruled portions overeed by iee; stippled portions corered by water. Direc
tion of dralnage indicated by arrows.

With the retreat of the ice to the north a final general filling upon which the present flood plain gravel fans at the mouths of the streams. The
grom valley fillings are probably composed mainly of glacial materials, but the filling of the inequalities and the building of the upper portion of the deposits
is doubtless to be assigned to post-Glacial deposition Retreat of the ice.-The peculiar climatic condthe a more temperate climate, and the ice sheet radually contracted and finally disappeared. It eems probable that the ice in the Elkland-Tioga change, with the result that, instead of a gradual of the sheet for some miles from its edge became essentially stagnant. Whether the cessation of otion took place while the uplands were still ature of the morainal terraces along the valleys it ill at or near the level of the highest. hills of the Chemung areas, though in some of the southwardwhat later period. In the final stages the ice was nfined to long, narrow masses occupying the valys and ravines and was clearly motionless. his stage the drainage usually followed along on or both sides of the ice masses and found outlets y routes often eircuitous and complex into the Ansonia. The most interesting of these drainage

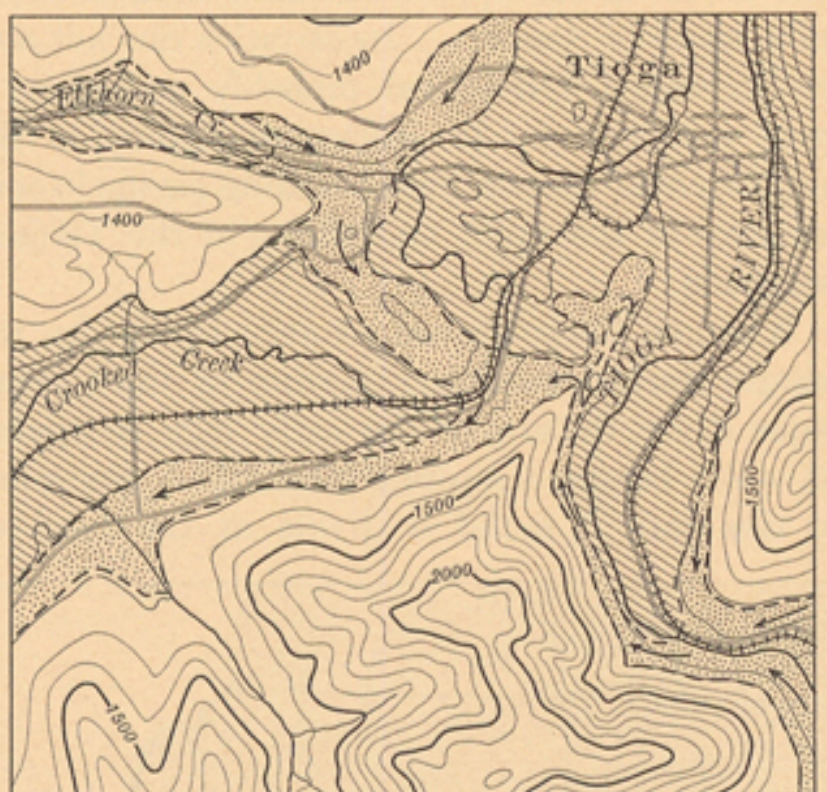

FIs. 3.-Map showing drainage conditions in the vieinity
of Tioga during the final retreat of the ice.

peculiarities was in the vicinity of Tioga. Fig. 3 ows by means of arrows and patterns the cours the streams in this vicinity in relation to the ice fosses and to the surrounding hills. The escape Tioga Valley and ponded in front of the ice lying the north of Tioga, through a sharp noteh cut to depth of nearly 50 feet across the nose of rock outh of Tioga, is a notable feature.

It is unlikely that the ice at any one time was tagnant over the whole area of the quadrangles, the motion probably continuing in the north long fter it had ceased in the regions to the south, or hose areas. The morainal deposits described as occurring at many points in the two quadrangles nark halts in the retreat, or possibly readvances of ctive to the very front. eries of long, narrow glacial lakes came into existeys of the Tioga and Cowanesque ed with sediments, parts of which are represented by the valley fillings and clays
previously described. The waters, as in the Kansan or pre-Kansan invasion and at the time of the Wisconsin advance, rose until they passed into the
stream leading southward from Ansonia. With the final disappearance of the ice, however, the streams returned to their pro

POST-GLACLAL HISTORY

As the valleys were successively opened up by the retreat of the ice the streams of the steeper ones entered actively upon the work of removing the lacial deposits of their bottoms and reducing them their former condition. The deposits thus been carried to the broad, open valleys of gentle slope, where they have been incorporated in the

.

The only other deposits which are assigned to post-Glacial time are the poorly assorted gravels of certain of the torrential streams, the marsh deposits occurring in poorly drained portions of the flood lains and in drift-obstructed valleys or in drift along the rivers.

The small amount of erosion and the correspondingly limited deposition, together with the slight leaching and oxidation of the drift, seem to indicate post-Glacial time which in length is but a small fraction of that which elapsed between the earliest fraction of that which elapsed between the earl
and the latest invasion of the ice in this region. ECONOMIC GEOLOGY at the local furnace. oints in the Elkland and Tioga quadrangles, but present are effectually concealed by later deposof sand and gravel.

Or. -Gravels oceur in abundance at many points, especially along the larger streams and in the morainal and glacial terrace deposits shown on the and and deposits are especially prominent at the junclong the east side of the valley of the latter from Tioga to Lawrenceville. The principal use of the ravel is as road metal on the roads built upon the soft loamy top of the flood plain along the rivers. The sand is used to some extent in mortar and plaster.

Petroleum.-No petroleum has yet been found in the Elkland-Tioga area, although numerous wells have been sunk in search of it. The Gaines oil eld, however, is only 4 miles from the southvest corner of the Elkland quadrangle, and it is by no means improbable that profitable pools may at some future time be discovered in the area

The oil of the Gaines field is obtained from two

Flagstone.-Quarries have been opened in the horizons, the upper, known as the Atwell sand, green or reddish flags of the Cattaraugus formation, being about 700 feet below the top of the Cheand more rarely in the Chemung, at a considerable mung formation, and the lower, known as the number of points in the Elkland-Tioga area. Some $\quad$ Blossburg formation, occurring about 200 feet of the quarries have been operated intermittently higher. The geologic features which may be of for many years and considerable quantities of a significance in relation to the occurrence of oil in The Gaines pools are as follows: The location of the only one actively worked at present, is located near syncline and the Wellsboro anticline (fig. 4); a the base of the Cattarangus formation at the shallowing of that portion of the syncline opposite extreme eastern edge of the Tioga' quadrangle the field; a simultaneous change in the direction of between the forks of Cory Creek, east of Mansfield the synclinal axis; and the occurrence of the oil at (see fig. 6). This quarry has had a large output a point marked by a flattening of the dips. (see fig. 6). This quarry has had a large output
of a good quality of flags, some of which are said marked by a flattening of the dips.
It is probable that there are points in the Elkof a good quality of flags, some of which are said It is probable that there are points in the ElkThe product is mainly used in the adjacent regions rence of oil are as favorable as at Gaines, but the The product is mainly used in the adjacent regions
in northern Pennsylvania and southern New York. Limestome. - Although no thick beds of pure only by the drill. The condition at Gaines is in Limestone. - Although no thick beds of pure only by the drill. The condition at Gaines is in limestone are known to occur within the quad- harmony with the general mode of occurrence of
rangles, there are numerous beds of impure lime- oil in other regions, and in locating new wells rangles, there are numerous beds of impure lime- oil in other regions, and in locating new wells stone scattered through the Chemung formation. similar geologic conditions should probably be They appear to be best developed and purest in the sought for. Fig. 4 shows the approximate locaupper portion of the formation, within a limit of tions of the anticlinal and synclinal axes in the 100 feet or so from the bottom of the overlying Elkland and Tioga quadrangles, and their extenCattaraugus formation. The material from these sions in the surrounding regions, as determined by beds is frequently burned for lime for local use the Second Geological Survey of Pennsylvania.
as fertilizer, and was at one time quarried near
By its aid localities corresponding to the position Mansfield for use as a flux in the smelting of iron of the Gaines field can be approximately deter-

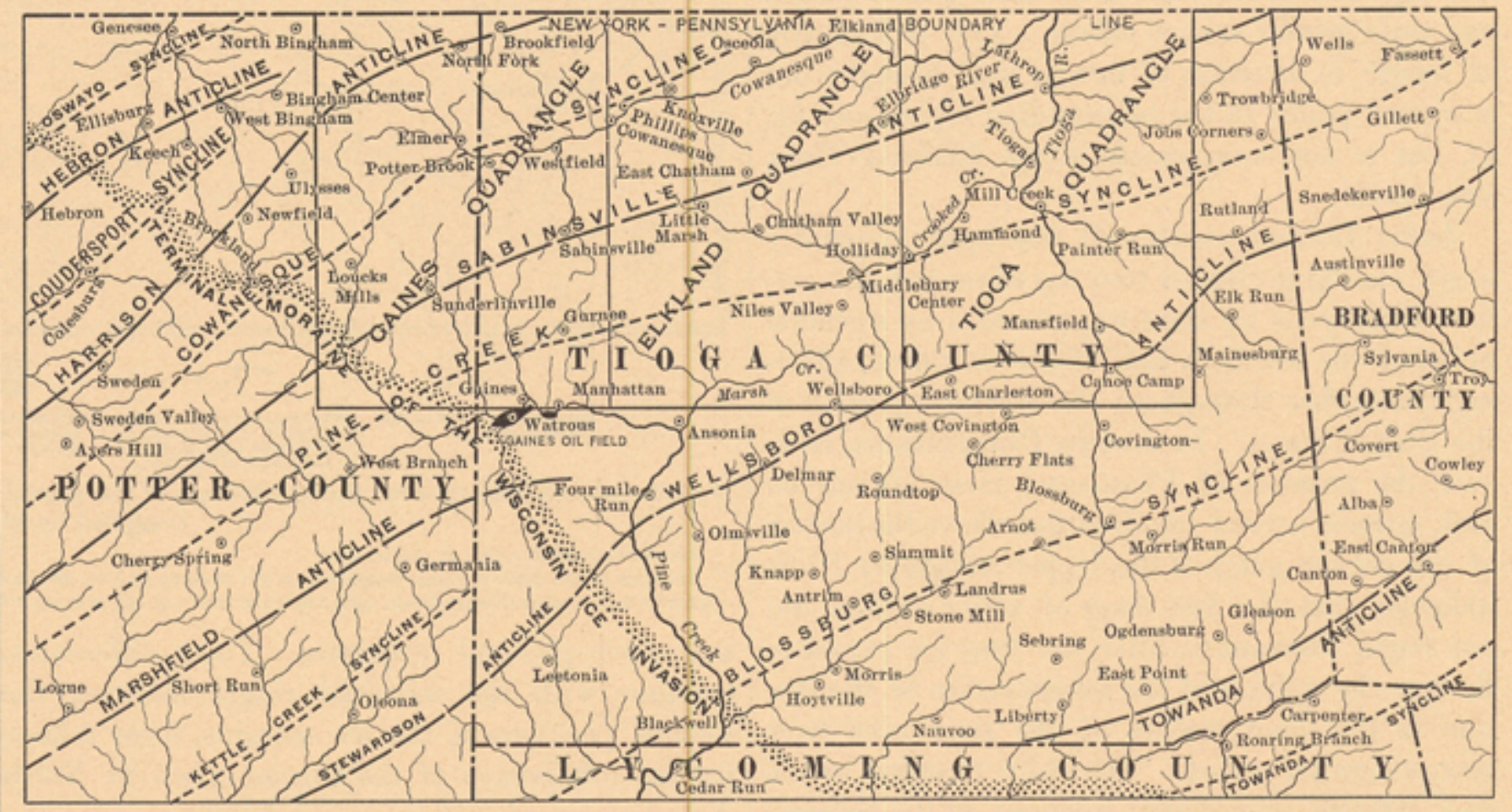

Frg. 4.-Sketch map of Gaines, Elkland, and Tioga quadrangles and adjacent portion of Pennsylvania.

Fire clay. $\mathrm{A}$ bed of fire clay has been exposed in $\mid$ In drilling for oil in the region it should be small pit on the high crest just east of the head- borne in mind that the Gaines field probably occur waters of Painter Run, in Rutland Township in in rock as strongly folded, or more strongly folded, the Tioga quadrangle. Its thickness and extent than those of any other oil field in Pennsylvania, are so slight and its position is so inaccessible that and that, while it can not be said that oil will not it is not likely to prove of economic value. $\quad$ be found in more strongly folded rocks, the chances Brick clay.-Buff and pinkish clays showing for finding it in paying quantities appear to be trongly contorted laminations have been noted in better in regions of gentle dip. Fig. 1, on page 5, the beds or banks of several of the streams entering shows, by means of contour lines at 100-foot interthe Tioga River from the west in the southern por- vals, the elevation and conformation of the uppe longs to the quadrangle. The material sura of previous page, and like other clays of the same location of areas of steep or slight dip in the field. Noss would doubtless be found, on testing, to fulfill Natural gas.-Gas has been found in a number e requirements of a good brick clay. Similar clays possibly occur at many other but beyond slight amounts burned in the immedi- 
ate vicinity of the wells, no use is made of it. It is probably somewhat more widely distributed than the oil, and wells drilled in seareh for it are more likely to meet with success. The most likely position for its occurrence is probably along the
crests of the anticlines, the positions of which may be seen from figs. 1 and 4 .

Iron ores.-Twenty-five or more years ago hematite iron ores were mined to a moderate extent at several points in the vicinity of Mansfield, and sequence of the development of large mines elsewhere in the country, especially in the Superior region, the mines about Mansfield were Superior ly The position and general characters of the ore mung, formation. The composition is shown in mung, formation. The composition is shown in the table given below, compiled from the report of Bradford and Tioga counties.

Partial analysis of iron ores of the Tioga quadrangle.

\begin{tabular}{|c|c|c|c|c|c|c|}
\hline & No.1. & No. 2. & No. 3. & No. 4 . & No. . . & 0.6. \\
\hline & 31.800 & 38.900 & 32.400 & 42.800 & 43.100 & 25.300 \\
\hline & & \begin{tabular}{|l|l|}
13.100 \\
\end{tabular} & \begin{tabular}{|l|l}
9.170 \\
\end{tabular} & & 1.800 & 4.740 \\
\hline & & 2.140 & 2.918 & & .922 & \\
\hline Phosphor's & .253 & .603 & .585 & .903 & .657 & .215 \\
\hline Sulphur. & . 034 & . 063 & .065 & 8 & .018 & . .026 \\
\hline $\begin{array}{c}\begin{array}{c}\text { Insoluble } \\
\text { residue }\end{array}\end{array}$ & 35.120 & 11.565 & 23.890 & 21.670 & 20.910 & 28.845 \\
\hline
\end{tabular}
No. 1 is a highly fossiliferous oolitic hematite from an out
crop on the highway about three-fourths of a mile east of
the southwest corner of the quadrangle. It was known to the Second Pennsylvania Survey as the Lower or Second ore Elkland and Tioga.

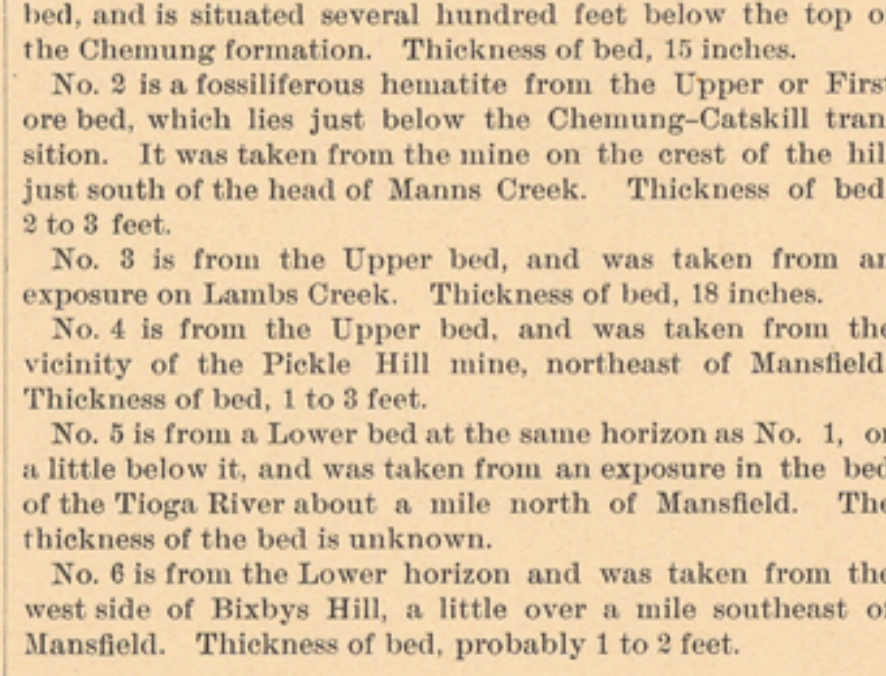

underlying rock, do not occur anywhere within quadrangles.

The glacial soils of the region, however, are fundamentally of sedentary derivation, the glacier having, on its advance, simply taken up the soil affords the most valuable soil, but because of the presence of heavy beds of nlaggy sandstones and distance, and then, as the ice melted, deposited it. formation, the areas are usually steep and roug The soils thus formed consist of heterogeneous and are not well adapted to cultivation. Buckaggregates of materials of all sizes from clay to wheat is the principal crop.

large fragments, the finer portions of which are The Oswavo formation gives extremely steep thoroughly decayed. Most of the soils of this type, slopes, and soils composed almost entirely of a mass like the true sedentary soils, agree in composition of sandstone fragments. Its areas are mostly forwith the underlying rock; hence the geologic ested and have in the past yielded quantities ot map showing the distribution of the rocks will also timber and of hemlock tan-bark. Occasional smal show, in a general way, the distribution of the soils. clearings have been made and small amounts of

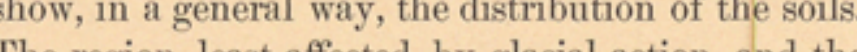
Many of the openings which were accessible at The region least affected by glacial action, and the
he time the analyses were made (about 1875) are one in which the soils most nearly resemble the he time the analyses were made (about 1875) are one in which the (t) rue sedentary soils, is the broad Chemung area few small areas at or near the very tops of the To the the Croga quadrangl, thicker and more of the material is of foreign deri- extent is so limited and its position so inaccessible

on the Areal Geology map. Hematite ore has been thicker and more of the material is of foreign deri- extent is so limited and its position so inaccessible reported as occurring beneath a portion of Wellsboro, and on one of the high hills near the crest of general way to the character of the underlying he anticline at a point about 8 miles southeast of Koxville; a a pese The limonite bed described in connection with the be in those locations where the soil most nearly Mauch Chunk formation as occurring east of the head of Painter Run, though thicker than the hemtite beds about Mansfield, is not likely to prove of any value.

slopes, and gives soils most nearly resembling quad- those of sedentary origin. It underlies the broad

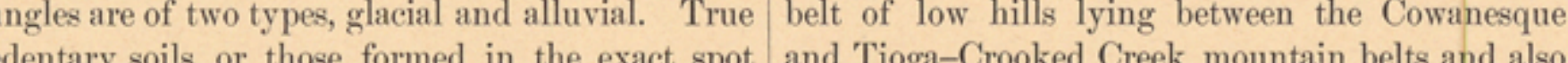
where found and composed of the insoluble sandy the low belt to the south of the latter. It includes and clayey products of decay of the immediately all the valuable farming land except that along the
The outcrops of the Sharon conglomerate are of till more limited extent and the resulting soils are slight as to be negligible.

The alluvial soils are partly the result of deposition by glacial streams and partly the result of the deposition of fine sediments upon the flood plains of the larger streams in recent times. The glacial alluvium is irregular in its distribution, covers but a small area, and is unimportant as a soil. The flood-plain alluvium, however, furnishes the superior tobacco. richest soil of the region and gives fine crops of a 

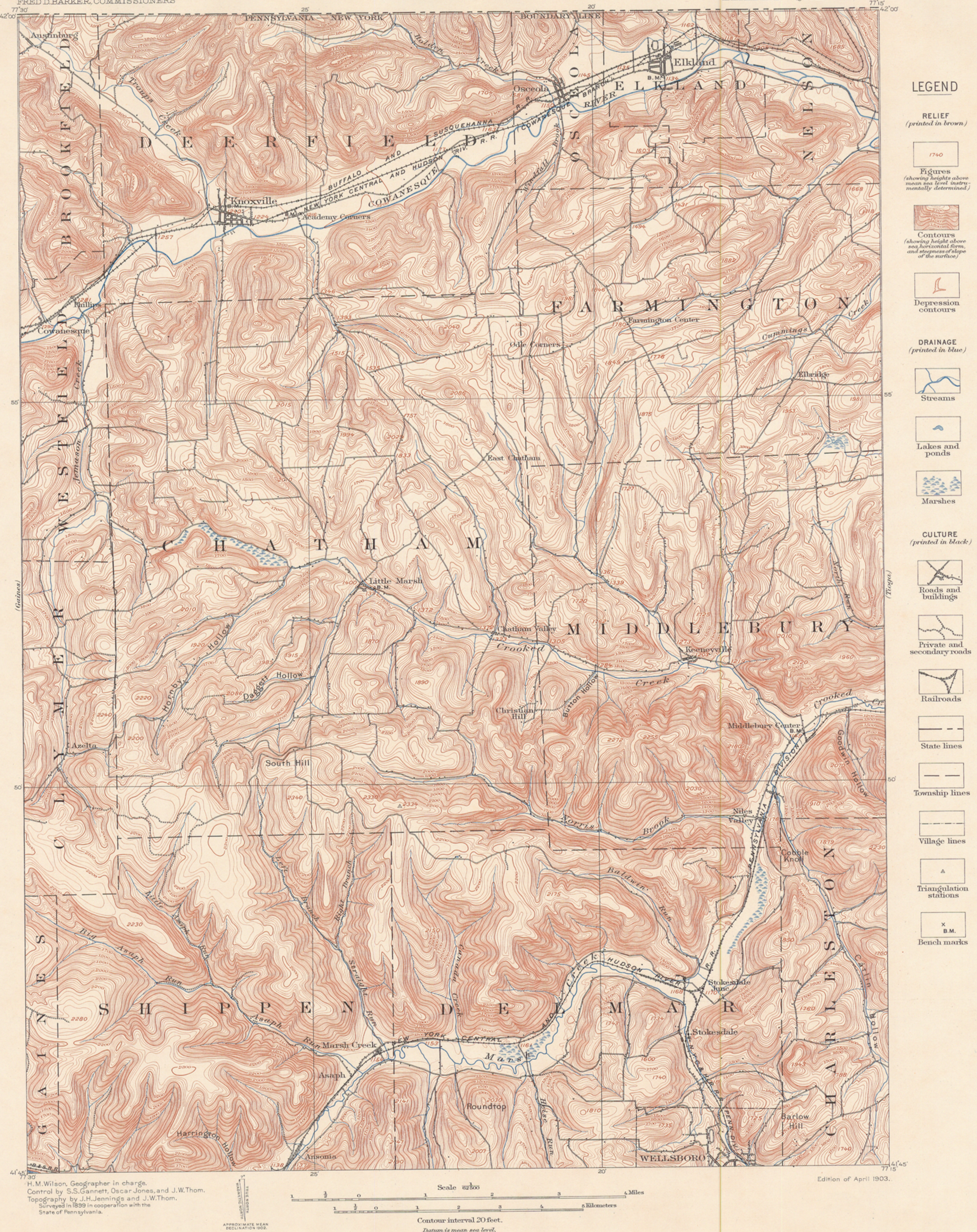


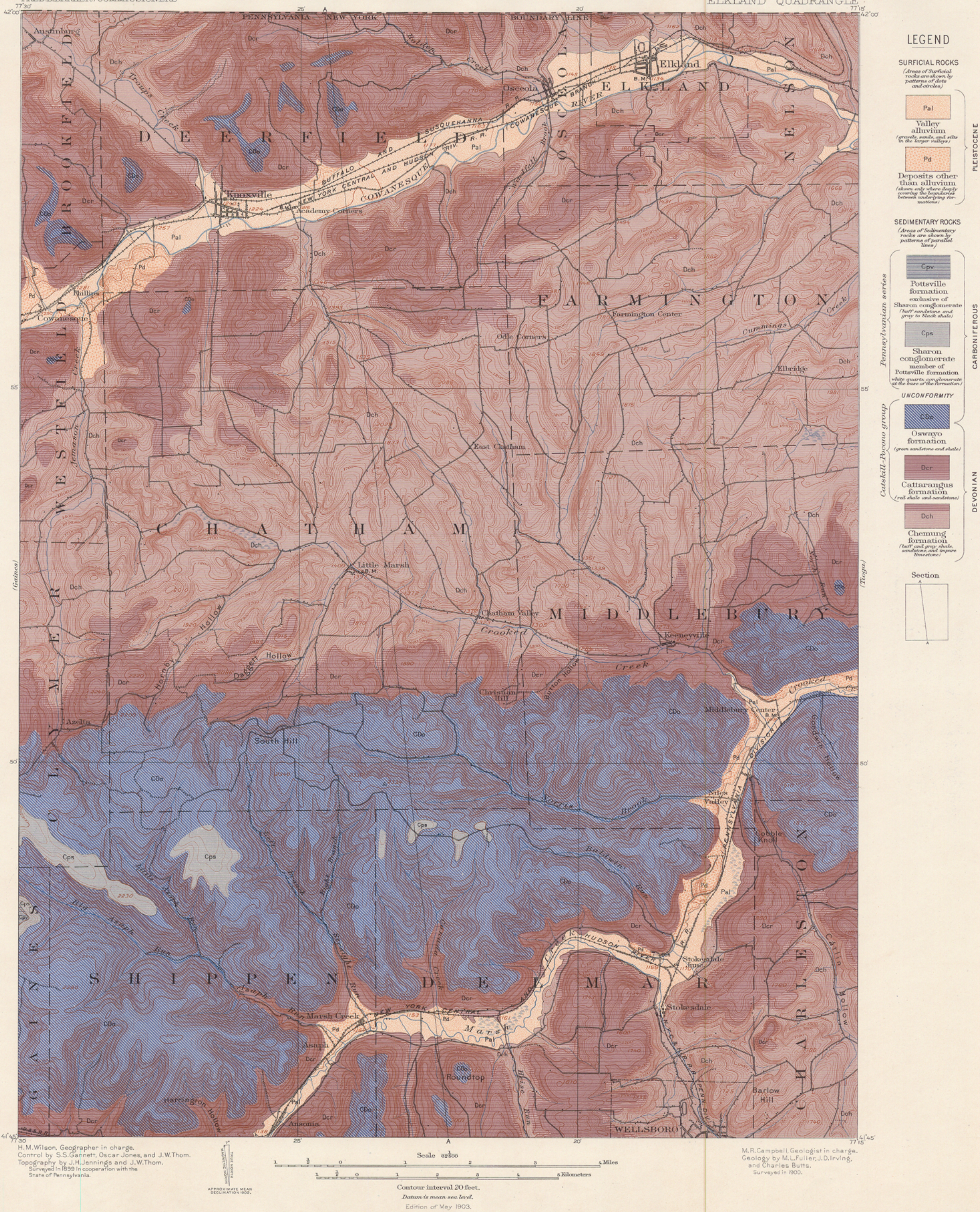




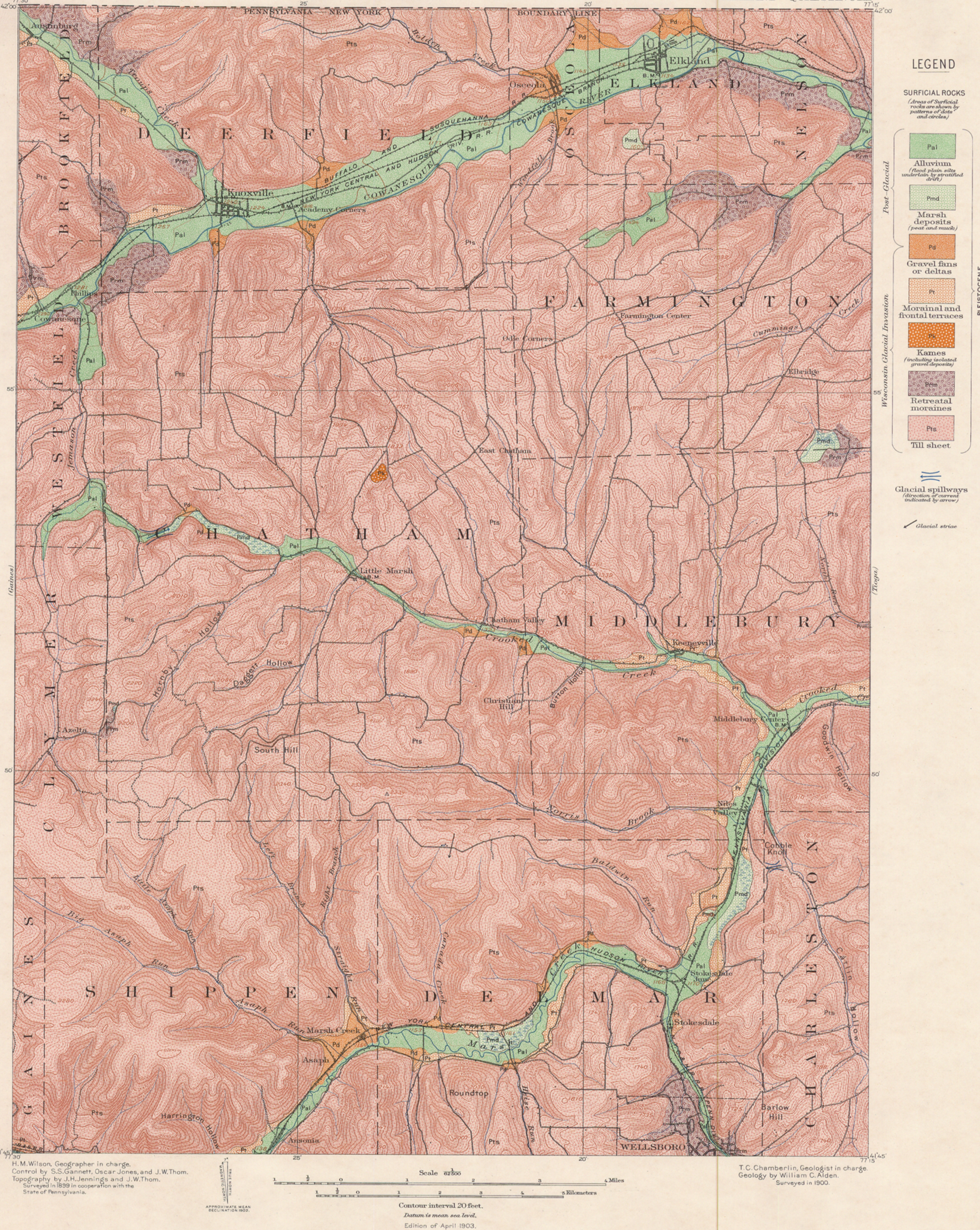




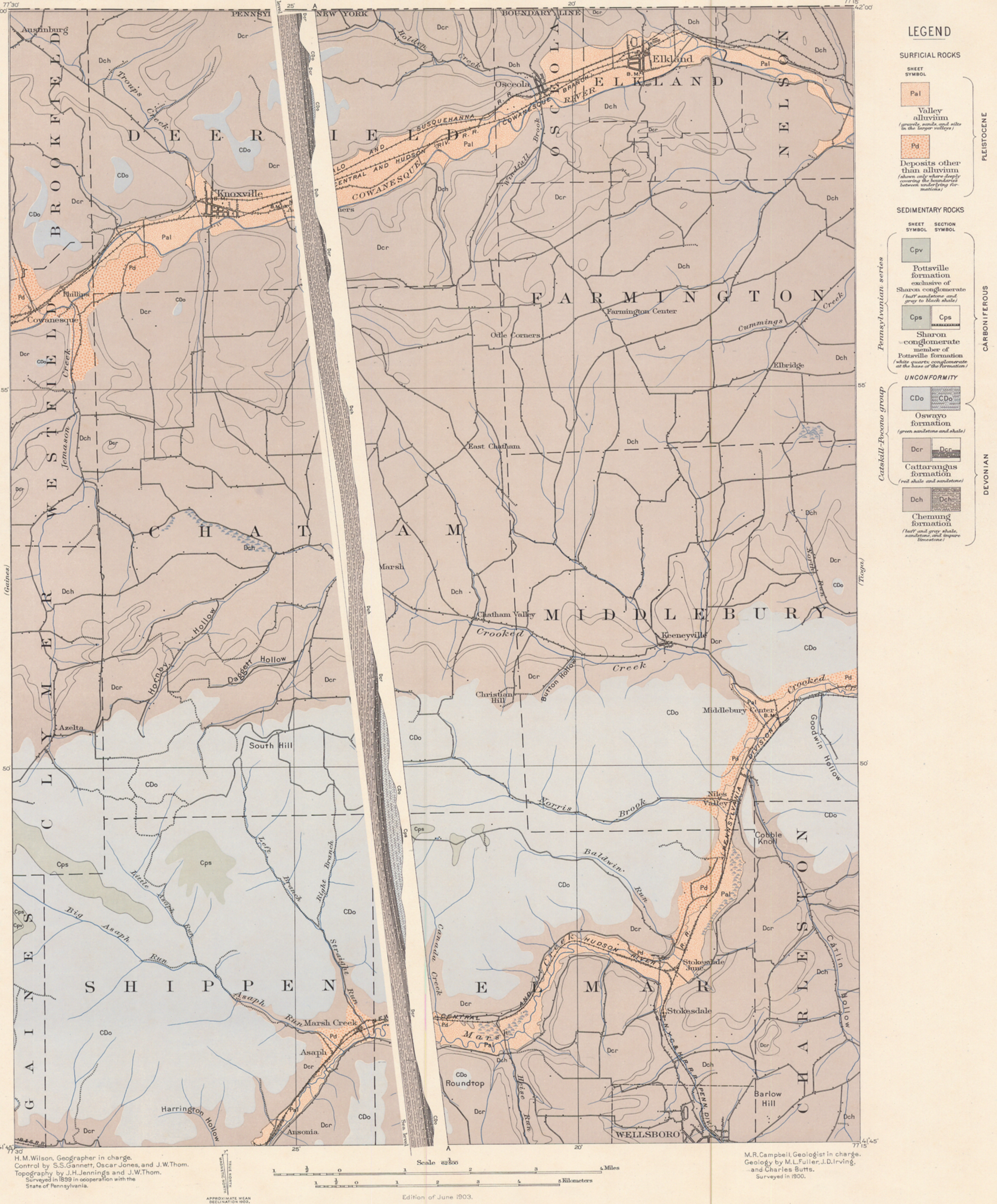




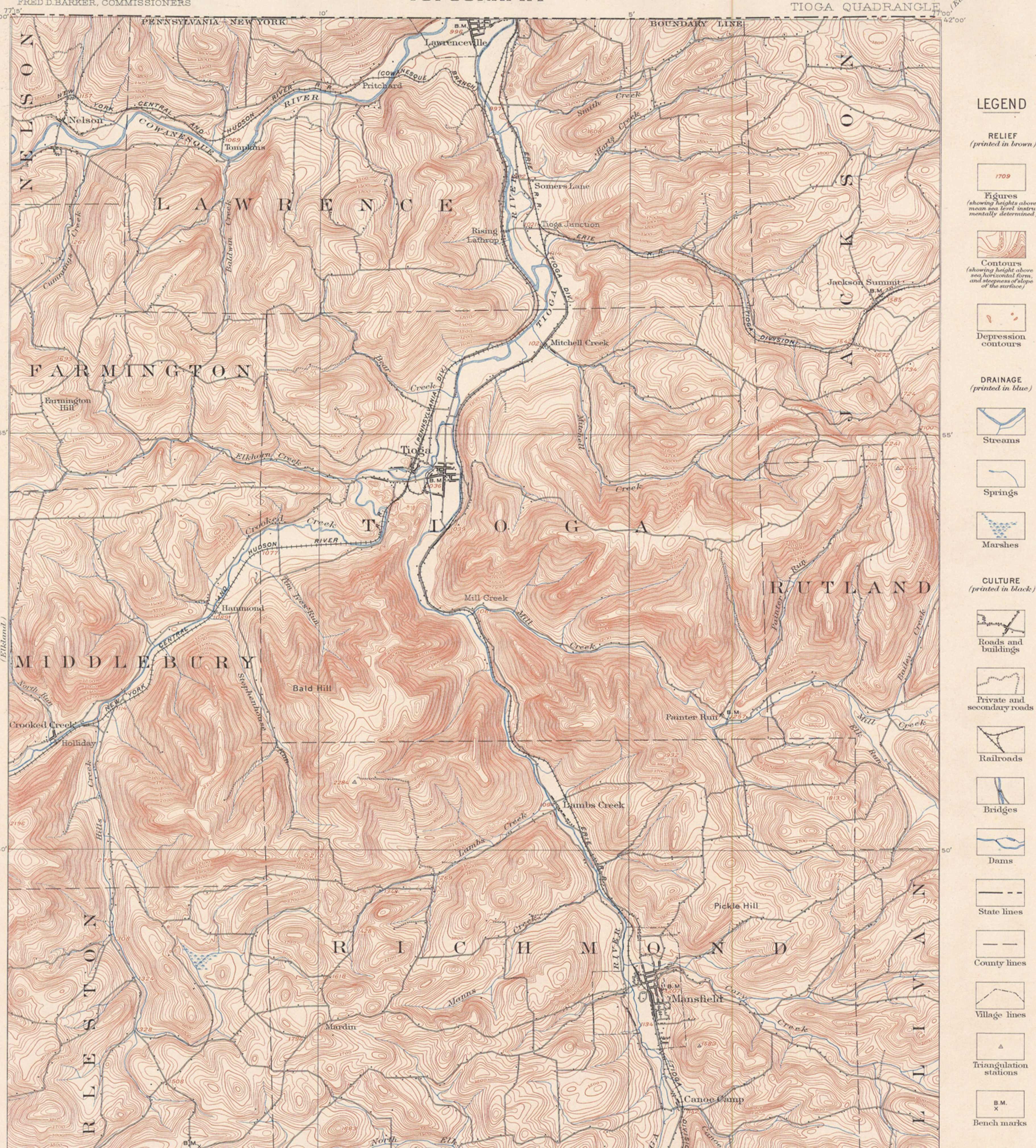




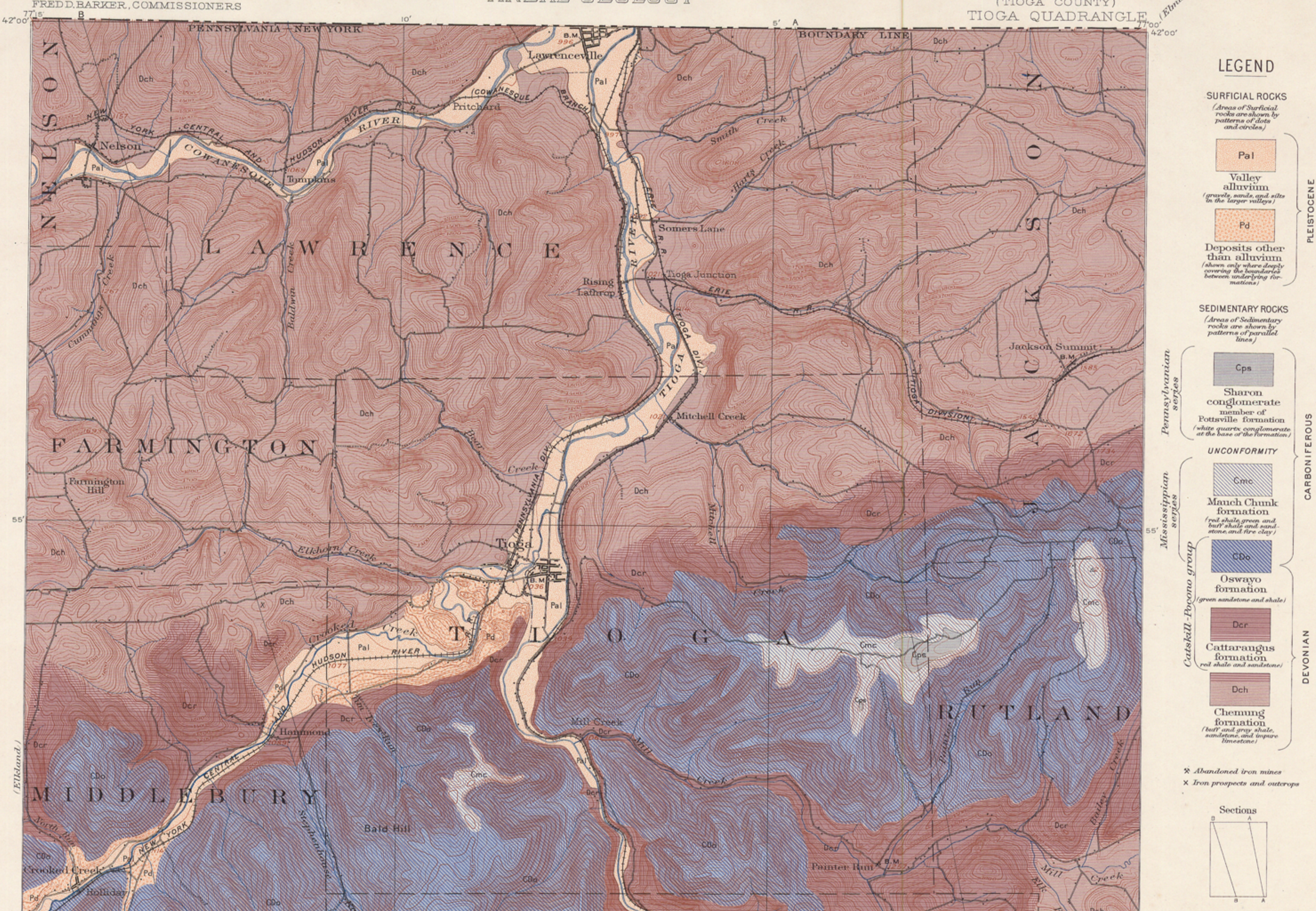




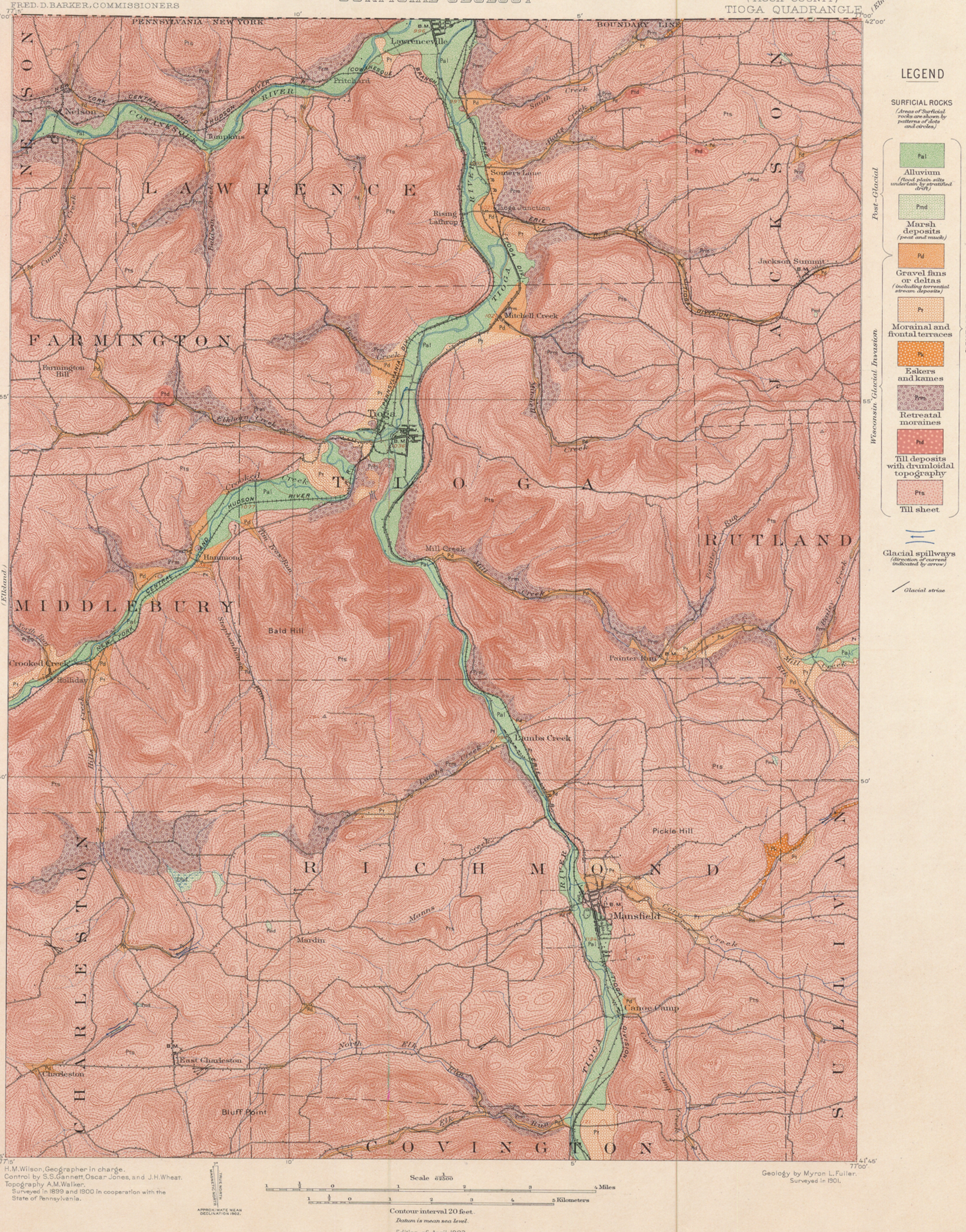



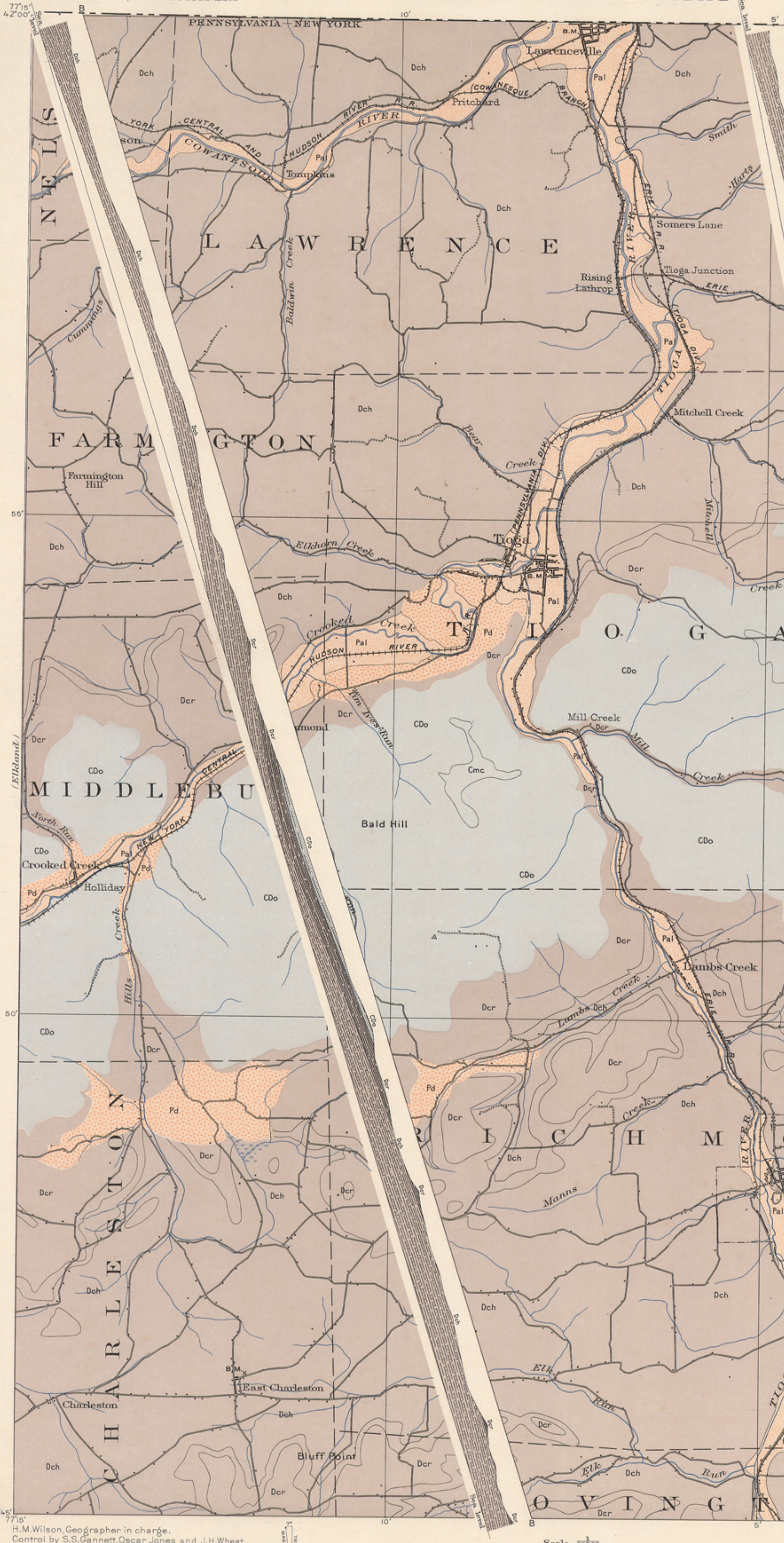
CDLUMNAR SECTIDN

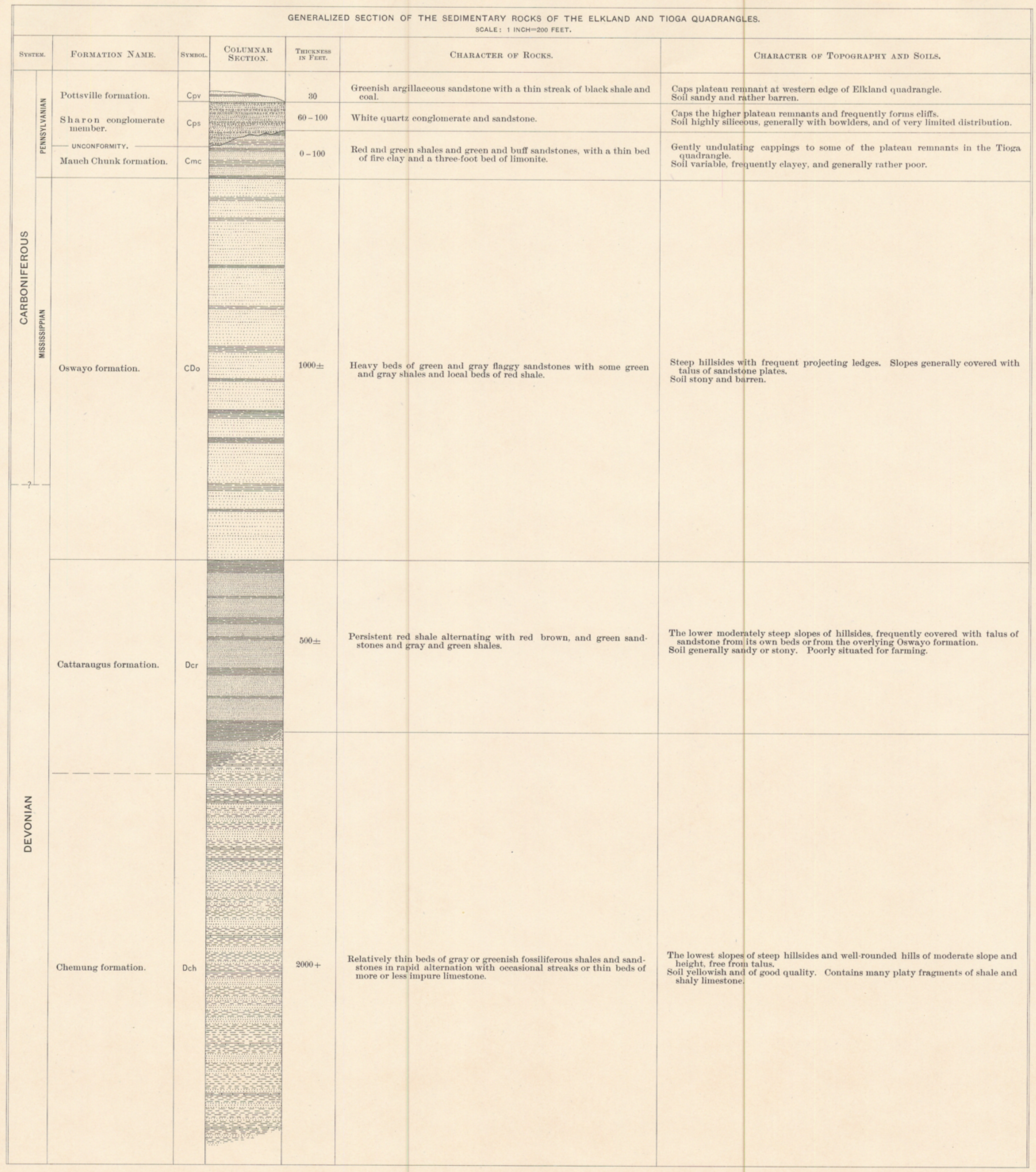


PENNSYLVANIA

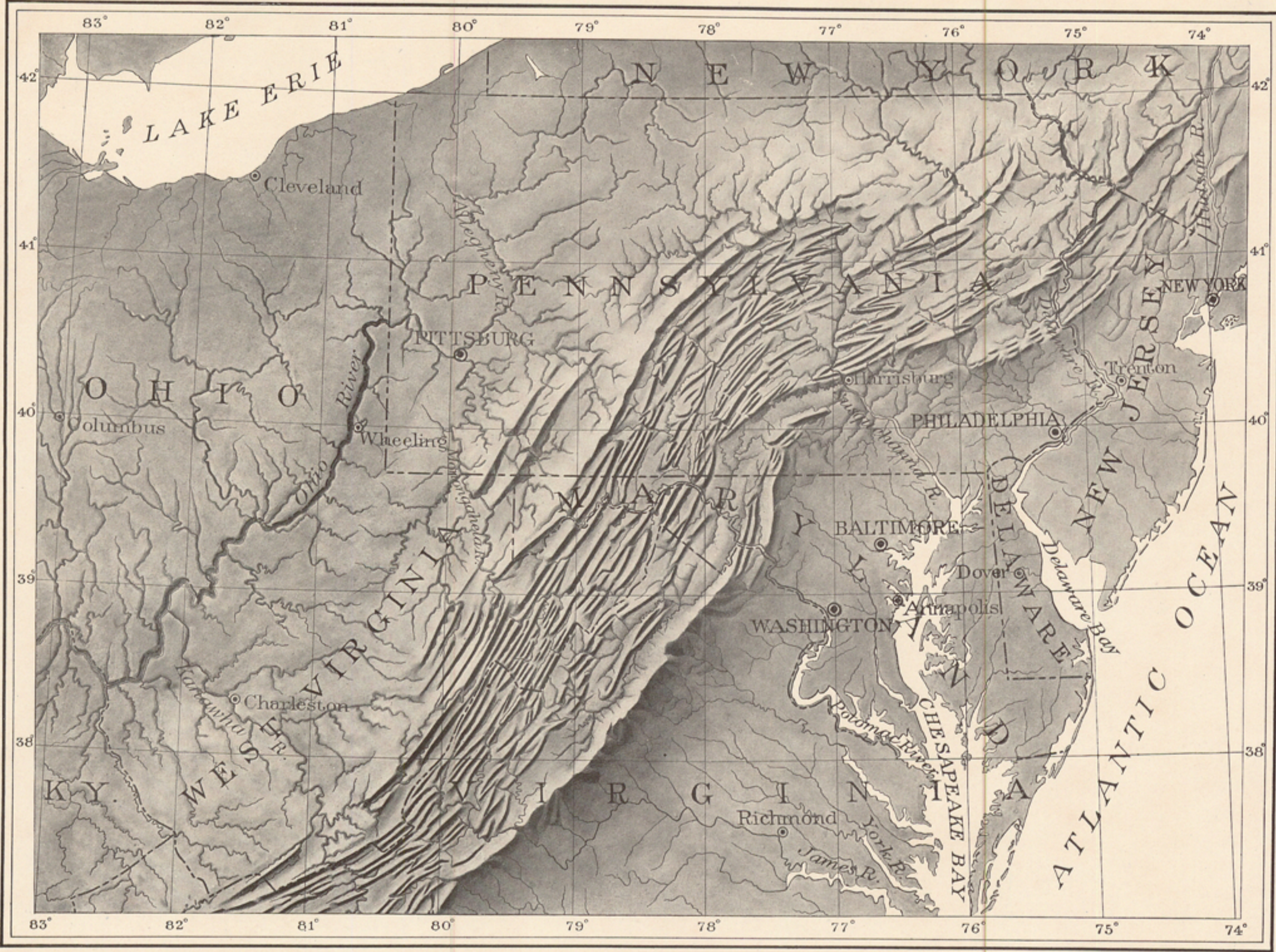

Fig. 5.-RELIEF MAP OF THE NORTHERN APPALACHAN MOUNTAINS.
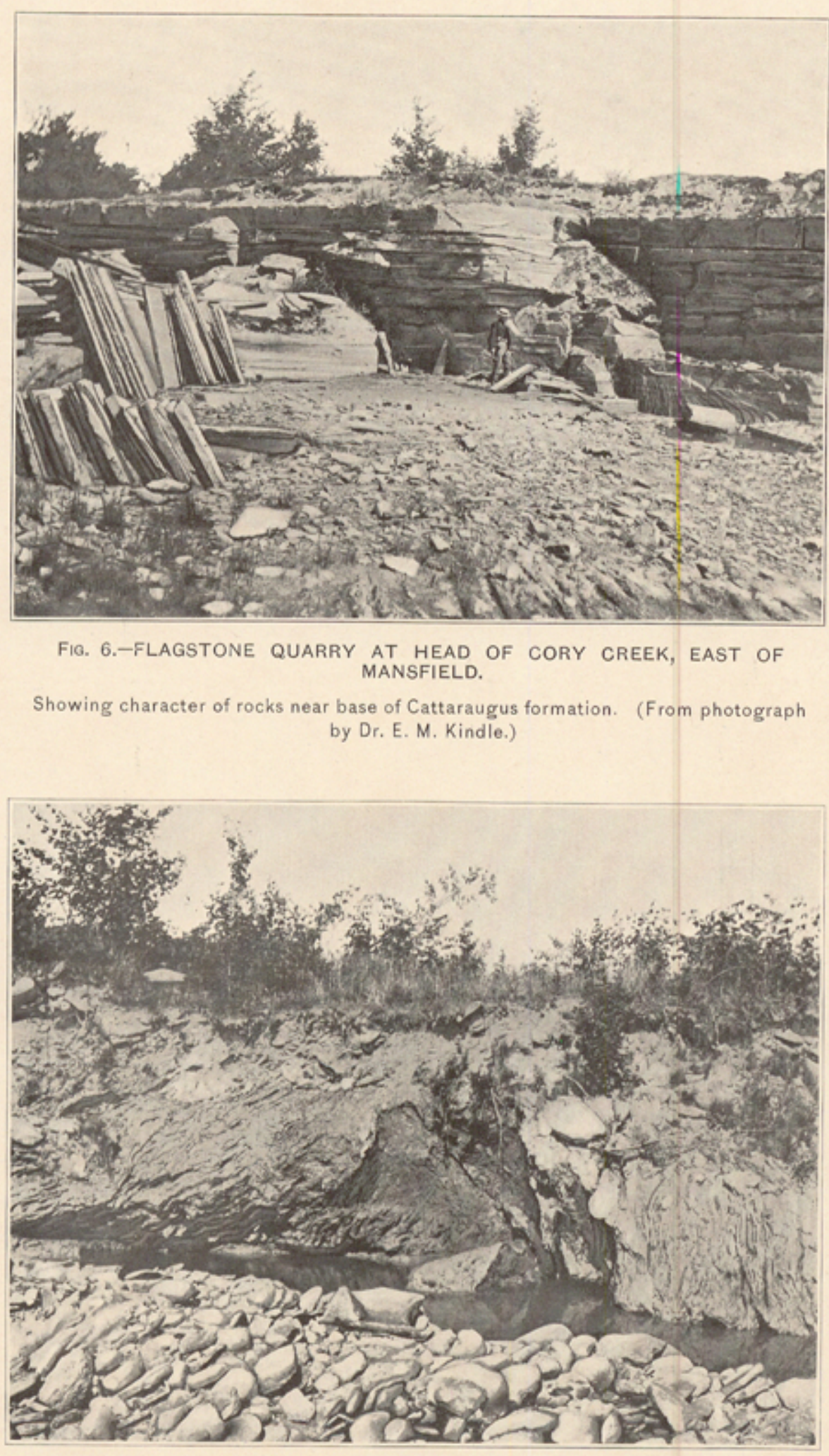

FIG. 8.-TORRENT GRAVEL IN BED OF STREAM AND SECTION OF
GLACIAL CLAY SHOWING CONTOBTIONS DUE TO CREP.
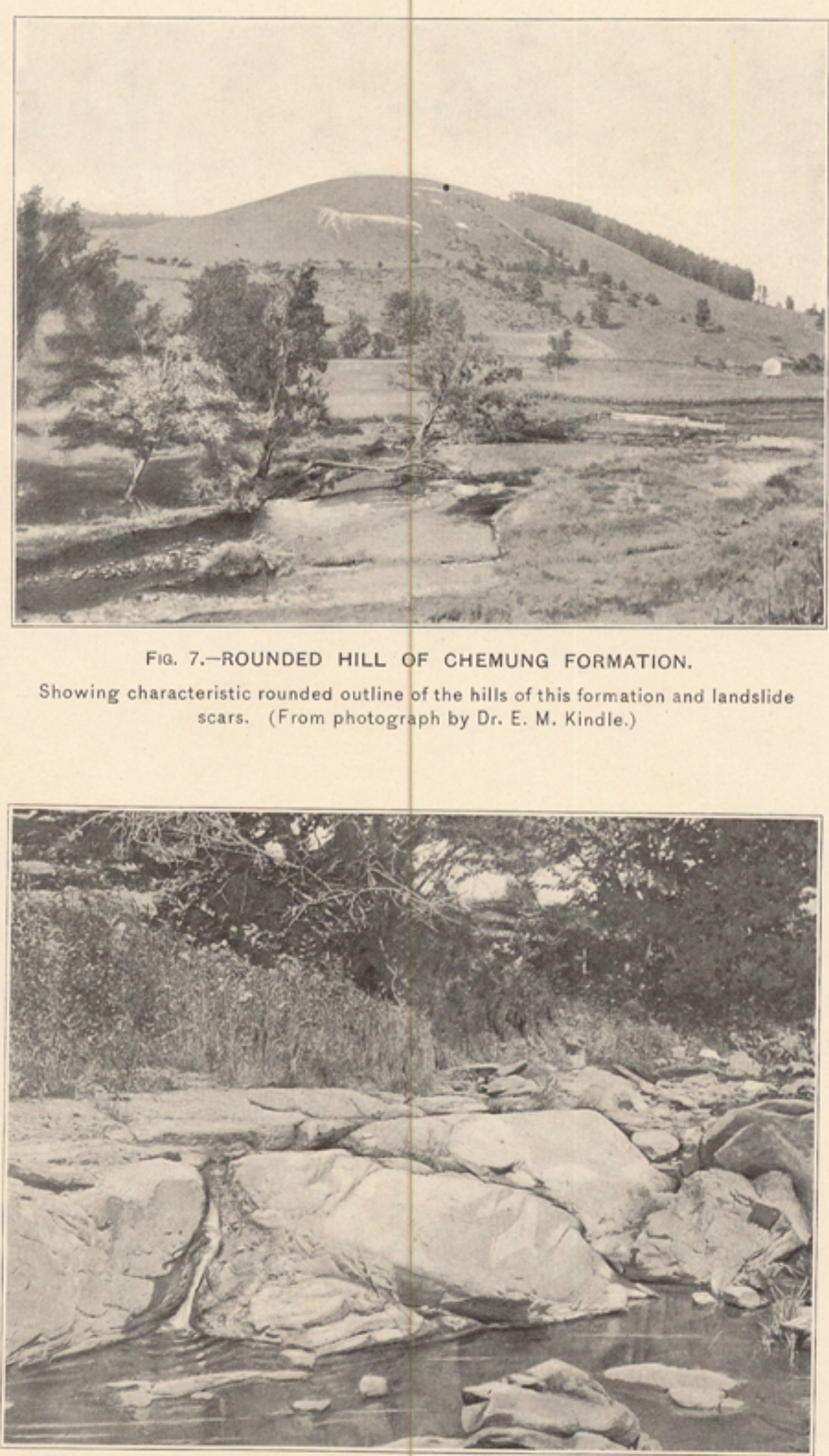

Fia. 9.-CONCRETIONARY MASSES IN THE CHEMUNG FORMATION A FEW
MILES NORTHEAST OF THE TIOGA QUADRANGLE, 
redeposited as beds or trains of sand and clay, deposits. Some of this glacial wash was deposited acteristic ridges and mounds of sand and gravel, material deposited by the ice is called glacial drift; that washed from the ice onto the adjacent
land is called modified drift. It is usual also to class as surficial rocks the deposits of the sea and of lakes and rivers that were made at the same time as the ice deposit.

$$
\text { AGES OF ROCKS }
$$

Rocks are further distinguished according to their relative ages, for they were not formed all history. Classification by age is independent of
origin; igneous, sedimentary, and surficial rocks origin; igneous, sedime

may be of the same age.
When the predominant material of a rock mass is essentially the same, and it is bounded by rocks of different materials, it is convenient to call the mass throughout its extent a formation, and such a formation is the unit of geologic mapping.

designated a system. The time taken for the the time taken for that of a system, or some larger fraction of a system, a period. The rocks are mapped by formations, and the formations are are mapped by formations, and the formations are
classified into systems. The rocks composing a system and the time taken for its deposition are system and the time taken for its deposition are
given the same name, as, for instance, Cambrian given the same name, as,
system, Cambrian period.

As sedimentary deposits or strata accumulate the younger rest on those that are older, and the relative ages of the deposits may be discovered by observing their relative positions. This rela-
tionship holds except in regions of intense turbance of the beds has been so great that their determine the relative ages of the beds from their positions; then fossils, or the remains of plants positions; then fossils, or the remains of plants
and animals, are guides to show which of two or more formations is the oldest.

Strata often contain the remains of plants and animals which lited in the sea or were washed from the land into lakes or seas or were buried in

tain the remains of life are called fossiliferous. By studying these remains, or fossils, it has been found that the species of each period of the earth
history have to a great extent differed from those of other periods. Only the simpler kinds of rocks were deposited. From time to time more lived on in modified forms life became more
varied. But during each period there lived peculvaried. But during each period there lived pecul-
iar forms, which did not exist in earlier times iar forms, which did not exist in earlier times
and have not existed since; these are characterand have not existed since; these are character-
istic types, and they define the age of any bed of rock in which they are found. Other types passed on from period to period, and thus linked the systems together, forming a chain of life from the time of the oldest fossiliferous rocks to the positions, the characteristic fossil types found positions, the characteristic fossil types found in
them may determine which was deposited first.

Fossil remains found in the rocks of different Fossil remains found in the rocks of different
areas, provinces, and continents afford the most areas, provinces, and continents afford the most
important means for combining local histories important means for com
into a general earth history. of strata, the history of the sedimentary rocks is divided into periods. The names of the periods in proper order (from new to old), with the colors and symbol assigned to each, are given in the
table in the next column. The names of certain subdivisions and groups of the periods, frequently used in geologic writings, are bracketed agains the appropriate period names.

To distinguish the sedimentary formations of any one period from those of another the patterns for the formations of each period are printed in thus forming another gradation into sedimentary in tunnels and channels in the ice, and forms charknown as osars, or eskers, and kames. Th at one time, but from age to age in the earth's deposition of a formation is called an epoch, and disturbance; sometimes in such regions the dis. position is reversed, and it is often difficult to surficial deposits on the land. Rocks that con. patt marine life existed when the oldest fossiliferous complex kinds developed, and as the simpler ones

When two formations are remote one from the

Colors and patterns.-To show the relative ages the appropriate period-color, with the exception \begin{tabular}{l|l} 
of the one at the top of the column (Pleistocene) & colors. A symbol for mines is introduced at each the earth's surface to wrinkle along certain zones. \\
and the one at the bottom (Archean). The sedi- & occurrence, accompanied by the name of the In places the strata are broken across and the
\end{tabular} mentary formations of any one period, excepting rom one another by different patterns, made o parallel straight lines. Two tints of the perior color are used : a pale tint is printed evenly ove the whole surface representing the period; a dark
tint brings out the different patterns representing formations. Each formation is furthermore give

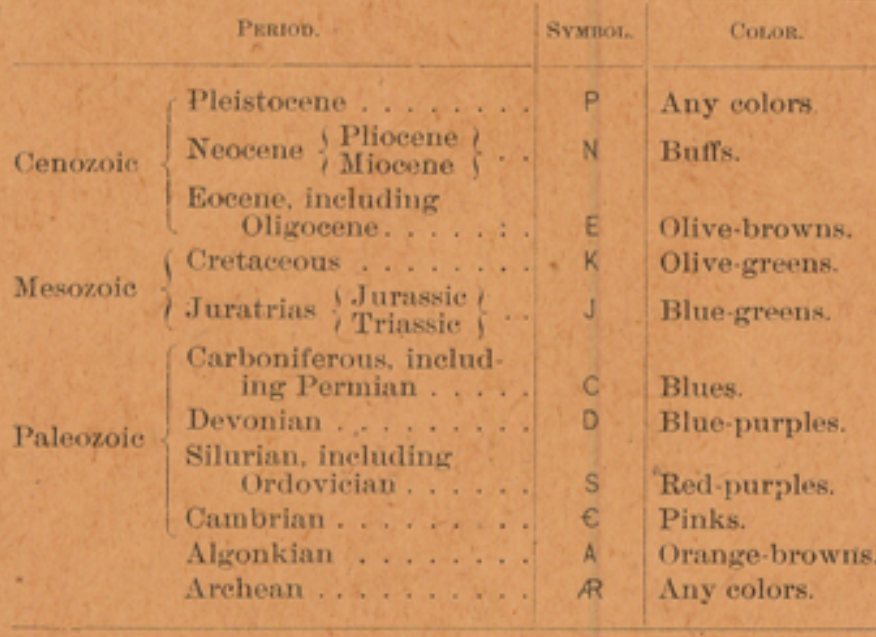

a letter-symbol composed of the period letter com bined with small letters standing for the, formain the case of a sedimentary formation ground in the color of the period to which the formation is supposed to belong, the letter-symbol of the period being omitted.

The number and extent of surficial formations, hiefly Pleistocene, render them so important that,
to distinguish them from those of other periods and from the igneous rocks, patterns of dots and and from the igneous rocks, patterns
circles, printed in any colors, are used. The origin of the Archean rocks is not fully settled. Many of them are certainly igneous. Whether sedimentary rocks are also included is not determined. The Archean rocks, and all ever age, are represented on the maps by pattern consisting of short dashes irrregularly placed. These are printed in any color, and may be darker or lighter than the background. If the rock is a wavy parallel lines. If the metamorphic rock is known to be of sedimentary origin the hachure patterns may be combined with the parallel-line atterns of sedimentary formations. If the rock is recognized as having been originally igneous, attern.

Known igneous formations are represented by patterns of triangles or rhombs printed in any rilliant color. If the formation is of known age he letter-symbol of the formation is preceded by If the age of the formation is unknown the letter-symbol consists of small letters which suggest the name of the rocks.

THE VARIOUS GEOLOGIC SHEETS.

Areal geology sheet.-This sheet shows the areas occupied by the various formations. On
the margin is a legend, which is the key to the map. To ascertain the meaning of any particular colored pattern and its letter-symbol on the map yymbol in the legend, where he will find the and and description of the formation. If it is desired to find any given formation, its name should be sought in the legend and its color and pattern noted, when the areas on the map corresponding in color and pattern may be traced out.

The legend is also a partial statement of the The legend is also a partial statement of the
geologic history. In it the symbols and names placed in the order of age, so far as known, the oungest at the top.

Economic geology sheet.-This sheet represents the distribution of useful minerals, the occurrence graphy and to the geologic formations. All the formations which appear on the historical geology heet are shown on this sheet by fainter color pat. terns. The areal geology, thus printed, affords a
subdued background upon which the areas of productive formations may be emphasized by strong
colors. A symbol for mines is introduced at each are arranged, in columnar form, according to the
origin of the formations - surficial, sedimentary, origin of the formations - surficial, sedimentary,
and igneous - and within each group they are est, showing their relations to the features of topoof the one at the top of the column (Pleistocene)
and the one at the bottom (Archean). The sedi.

principal mineral mined or of the stone quarried. parts slipped past one another. Such breaks are Structure-section sheet.- This sheet exhibits $t$ In cliffs, canyons, shafts, and other natural and artificial cuttings, the relations of different beds to one another may be seen. Any cutting which exhibits those relations is called a section, and the same name is applied to a diagram representing
the relations. The arrangement of rocks in the earth is the earth's structure, and a section exhibiting this arrangement is called a structure section. The geologist is not limited, however, to the natural and artificial cuttings for his information concerning the earth's structure. Knowing the manner of the formation of rocks, and having traced out the relations among beds on the surface, he can infer their relative positions afte they pass beneath the surface, draw section which represent the structure of the earth to a
considerable depth, and construct considerable depth, and construct a diagram
exhibiting what would be seen in the side of utting many miles long and several thousand feet deep. This is illustrated in the following figure

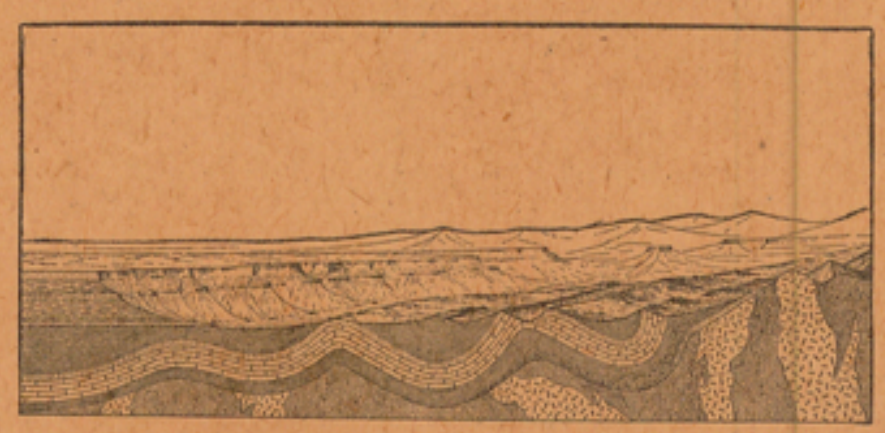

Fig. 2.-Sketeh showing a vertical section in the

The figure represents a landscape which is cut

off sharply in the foreground by a vertical plane, as

The kinds of rock are indicated in the sectio by appropriate symbols of lines, dots, and dashes. These symbols admit of much yariation, but the following are generally used in sections to repre ent the commoner kinds of rock
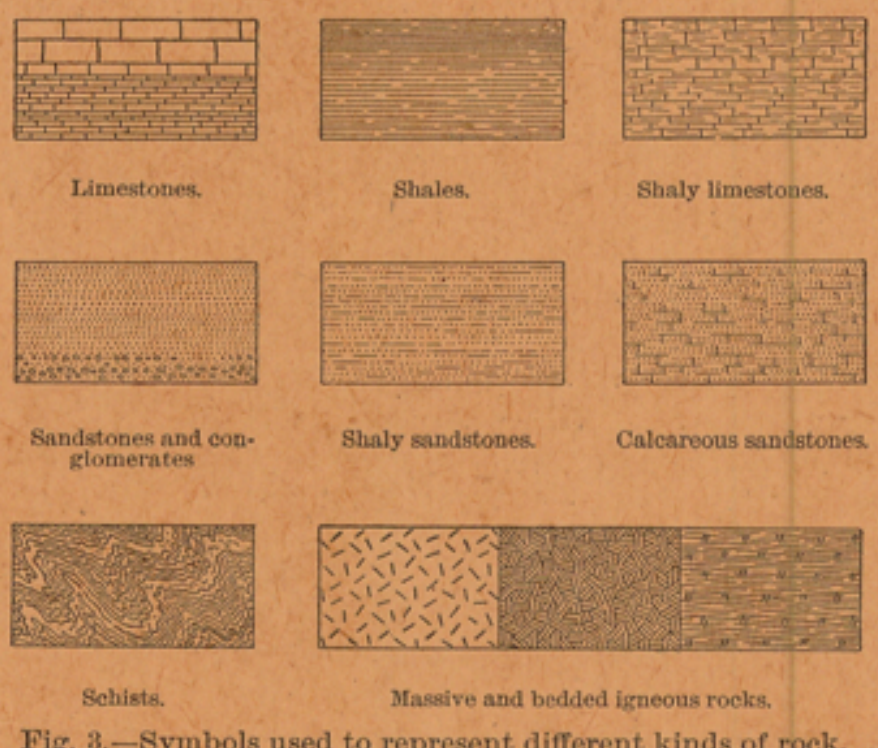

The plateau in fig. 2 presents toward the lower and an escarpment, or front, which is made up of sandstones, forming the cliffs, and shales, constituting the stopt

The broad belt of lower land is traversed by several ridges, which are seen in the section to correspond to beds of sandstone that rise to the urface. The upturned edges of these beds form the outerops of limestone and calcareous shales. Where the edges of the strata appear at the Where the edges of the strata appear at the
surface their thickness can be measured and the surface their thickness can be measured and the
angles at which they dip below the surface can be
observed. Thus their positions nnderoround can observed. Thus their positions underground can be inferred. The direction that the intersection
of a bed with a horizontal plane will take is called the strike. The inclination of the bed to the horizontal plane, measured at right angles to the strike, is called the dip.

When strata which are thus inclined are traced underground in mining, or by inference, it is frequently observed that they form troughs or arehes, such as the section shows. The arches are called anticlines and the troughs synclines. But the sandstones, shales, and limestones were deposited eneath the sea in nearly flat sheets. That they are now bent and folded is regarded as proof that
forces exist which have from time to time caused the earth's surface to wrinkle along certain zones

On the right of the sketch the section is con posed of schists which are traversed by masses of gneous rock. The schists are much contorted and their arrangement underground can not be inferred. Hence that portion of the section delineates what is probably true but is not In fig. 2 there are three sets of formations, disinguished by their underground relations. The first of these, seen at the left of the section, is the set of sandstones and shales, which lie in a horizontal position. These sedimentary strata are now high above the sea, forming a plateau, and
nowition. These sedimentary strata are heir change of elevation shows that a portion the earth's mass has swelled upward from lower to a higher level. The strata of this set ar parallel, a relation which is called conformable. The second set of formations consists of strats which form arches and troughs. These strata were once contintious, but the crests of the arche like those of the first set, are conformable.

The horizonal strata of the plateau rest upon the upturned, eroded edges of the beds of the second set at the left of the section. The over lying deposits are, from their positions, evidently ounger than the underlying formations, and the bending and degradation of the older strata must have occurred between the deposition of the older beds and the accumulation of the younger. When younger strata thus rest upon an eroder surface of older strata the relation between the two is an unconformable one, and their surface of contact is an unconformity.

The third set of formations consists of crystal line schists and igneous rocks. At some period of their history the schists were plicated by pres. sure and traversed by eruptions of molten roek. But this pressure and intrusion of igneous rocks have not affected the overlying strata of the second set. Thus it is evident that an interval of second set. Thus it is evident that an interval of
considerable duration elapsed between the forma tion of the schists and the beginning of deposition of the strata of the second set. During thi interval the schists suffered metamorphism; the were the scene of eruptive activity; and they were deeply eroded. The contact between the
second and third sets, marking a time interval second and third sets, marking a time interval
between two periods of rock formation, is another unconformity.

The section and landscape in fig. 2 are ideal, but they illustrate relations which actually oceur. The sections in the structuresection sheet are related to the maps as the section in the figure is face in the section correspond to the actual slopes face in the section correspond to the actual slopes
of the ground along the section line, and the depth from the surface of any mineral-producins or waterfrom the surface of any mineral-producing or water-
bearing stratum which appears in the section may bearing stratum which appears in the section
be measured by using the scale of the map. Columnar section sheet.- This sheet contains concise description of the rock formations which occur in the quadrangle. It presents a summary of the facts relating to the character of the rocks, the thicknesses of the formations, and the order f accumulation of successive deposits.

heading, and their characters are indicated in colne The thicknesses of formations are given in figures which state the least and greatest measurements. The average thickness of each formation is shown the column, which is drawn to a scale - usually 1000 feet to 1 inch. The order of accumulation of the sediments is shown in the columnar arrange. nent: the oldest formation is placed at the bottom of the column, the youngest at the top, and igne. ous rocks or surficial deposits, when present, are Thed in their proper relations.

The formations are combined into systems

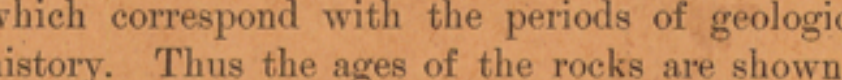
and also the total thickness of each system. The intervals of time which correspond to The intervals of time which correspond to
events of uplift and degradation and constitute interruptions of deposition of sediments are indi. cated graphically and by the word "unconformity." 
PUBLISHED GEOLOGIC FOLIOS

\begin{tabular}{|c|c|c|c|}
\hline o.* & Name of folio. & State. & Price. $\dagger$ \\
\hline & at & & Cents. \\
\hline & Livingston & Montana . . & 25 \\
\hline 2 & Ringgold . & Georgia-Tennessee & 25 \\
\hline $\begin{array}{l}3 \\
+4\end{array}$ & $\begin{array}{l}\text { Placerville } \\
\text { Kingston. }\end{array}$ & California. & 25 \\
\hline 5 & Kingston . & Tennessee & 25 \\
\hline$\ddagger 6$ & Chattanooga & Tennessee. & 25 \\
\hline$\ddagger z$. & Pikes Peak. & Golorado. & $\begin{array}{l}25 \\
25\end{array}$ \\
\hline 8 & Sewanee . & Tennessee & 25 \\
\hline †9 & Anthracite-Crested Butte & Golorado. & 50 \\
\hline 10 & Harpers Ferry & Va.-w. Va.-Md. & 25 \\
\hline 11 & Jackson & California... & 25 \\
\hline 12 & Estillville. & Va.-Ky.-Tenn. & 25 \\
\hline 13 & Fredericksburg & Maryland-Virginia & 25 \\
\hline 14 & Staunton & Virginia-West Virginia & 25 \\
\hline 15 & Lassen Peak & California . & 25 \\
\hline 16 & Knoxville. & Tennessee-North Carolina & 25 \\
\hline 17 & Marysville & Galifornia........ & 25 \\
\hline 18 & Smartsville & California & 25 \\
\hline 19 & Stevenson & Ala.-Ga.-Tenn. & 25 \\
\hline 20 & Cleveland. & Tennessee & 25 \\
\hline 21 & Pikeville & Tennessee & 25 \\
\hline 22 & McMinnville & Tennessee & 25 \\
\hline 23 & Nomini . & Maryland-Virginia & 25 \\
\hline 24 & Three Forks & Montana & 50 \\
\hline 25 & Loudon ... & Tennessee & 25 \\
\hline 26 & Pocahontas. & Virginia-West Virginia & 25 \\
\hline 27 & Morristown. & Tennessee & 25 \\
\hline 28 & Piedmont. & Maryland-West Virginia & 25 \\
\hline 29 & Nevada City Special & California & 50 \\
\hline 30 & Yellowstone National Park & Wyoming & 75 \\
\hline 31 & Pyramid Peak... & California. & 25 \\
\hline 32 & Franklin & Virginia-West Virginia & 25 \\
\hline 33 & Briceville & Tennessee & 25 \\
\hline 34 & Buckhannon & West Virginia & 25 \\
\hline 35 & Gadsden & Alabama & 25 \\
\hline 36 & Pueblo & Colorado & 50 \\
\hline 37 & Downieville. & California & 25 \\
\hline 38 & Butte Special & Montana & 50 \\
\hline 39 & Truckee & California . & 25 \\
\hline 40 & Wartburg & Tennessee & 25 \\
\hline 41 & Sonora & California & 25 \\
\hline 42 & Nueces & Texas & 25 \\
\hline 43 & Bidwell Bar & California . & 25 \\
\hline $44 . \quad 2 \quad>$ & Tazewell . . & Virginia-West Virginia & 25 \\
\hline 45 & Boise. & Idaho .......... & 25 \\
\hline 46 & Richmond & Kentucky & 25 \\
\hline 47 & London . & Kentucky & 25 \\
\hline
\end{tabular}

\begin{tabular}{|c|c|c|c|}
\hline No.* & Name of folio. & State. & Price. $\dagger$ \\
\hline & & & Cents. \\
\hline 48 & Tenmile District Special . & $\begin{array}{l}\text { Colorado } \\
\text { Oregon. }\end{array}$ & 25 \\
\hline 50 & $\begin{array}{l}\text { Rosebourg : } \\
\text { Holyoke. }\end{array}$ & Mass.-Conn. & \\
\hline 51 & Big Trees & California. & 25 \\
\hline 52 & Absaroka . & Wyoming . & 25 \\
\hline 53 & Standingstone & Tennessee & 25 \\
\hline 54 & Tacoma... & Washington & 25 \\
\hline 55 & Fort Benton . & Montana & 25 \\
\hline 56 & Little Belt Mountains & Montana & 25 \\
\hline 57 & Telluride & Colorado & 25 \\
\hline 58 & Elmoro . & Colorado & 25 \\
\hline 59 & Bristol & Virginia-Tennessee & 25 \\
\hline 60 & La Plata & Colorado & 25 \\
\hline 61 & Monterey & Virginia-West Virginia & 25 \\
\hline 62 & Menominee Special & Michigan & 25 \\
\hline 63 & Mother Lode District & California & 50 \\
\hline 64 & Uvalde .... & Texas : & 25 \\
\hline 65 & Tintic Special & Utah & 25 \\
\hline 66 & Golfax .... & California & 25 \\
\hline $6 z$ & Danville & Illinois-Indiana & 25 \\
\hline 68 & Walsenburg & Colorado... & 25. \\
\hline 69 & Huntington. & West Virginia-Ohio & 25 \\
\hline 70 & Washington. & D. G.-Va.-Md. . . & 50 \\
\hline 71 & Spanish Peaks & Colorado . & 25 \\
\hline 72 & Charleston & West Virginia & 25 \\
\hline 73 & Coos Bay & Oregon & 25 \\
\hline 74 & Coalgate & Indian Territory & 25 \\
\hline 75 & Maynardville & Tennessee & 25 \\
\hline 76 & Austin & Texas & 25 \\
\hline 77 & Raleigh & West Virginia & 25 \\
\hline 78 & Rome. & Georgia-Alabama & 25 \\
\hline 79 & Atoka. & Indian Territory & 25 \\
\hline 80 & Norfolk & Virginia-North Carolina & 25 \\
\hline 81 & Chicago. & Illinois-Indiana . . . . & 50 \\
\hline 82 & Masontown-Uniontown & Pennsylvania & 25 \\
\hline 83 & New York City ... & New York-New Jersey & 50 \\
\hline 84 & Ditney & Indiana & 25 \\
\hline 85 & Oelrichs & South Dakota-Nebraska & 25 \\
\hline 86 & Ellensburg & Washington....... & 25 \\
\hline $8 z$ & Camp Clarke & Nebraska . & 25 \\
\hline 88 & Scotts Bluff & Nebraska & 25 \\
\hline 89 & Port Orford & Oregon & 25 \\
\hline 90 & Granberry & N. Car.-Tenn. & 25 \\
\hline 91 & Hartville & Wyoming . & 25 \\
\hline 92 & Gaines & Pennsylvania-New York & 25 \\
\hline 93 & Elkland-Tioga & Pennsylvania & 25 \\
\hline 94 & Brownsville-Connellsville & Pennsylvania & 25 \\
\hline
\end{tabular}

* Order by number. 